\title{
Liberalization and Nationalization in South America: A Comparative Analysis of Economics Impact Through Telecommunications and Electricity Sectors
}

\author{
Arturo Davalos Yoshida ${ }^{1,2}$, Richard-Jesus Gil-Herrera ${ }^{1}$ \\ ${ }^{1}$ Doctorate Department, Faculty of Social Sciences, American University of Europe, Cancun, Mexico \\ ${ }^{2}$ ABS Consulting Group, La Paz, Bolivia \\ Email address: \\ arturo.davalos@abs-cgroup.com (A. D. Yoshida), richard.dejesus@aulagrupo.es (Richard-Jesus Gil-Herrera), \\ richard.dejesus@unir.net (Richard-Jesus Gil-Herrera), rgil05@correo.ugr.es (Richard-Jesus Gil-Herrera)

\section{To cite this article:} \\ Arturo Davalos Yoshida, Richard-Jesus Gil-Herrera. Liberalization and Nationalization in South America: A Comparative Analysis of \\ Economics Impact Through Telecommunications and Electricity Sectors. International Journal of Business and Economics Research. \\ Vol. 9, No. 4, 2020, pp. 211-227. doi: 10.11648/j.ijber.20200904.18
}

Received: May 24, 2020; Accepted: June 17, 2020; Published: July 4, 2020

\begin{abstract}
To achieve better levels of development, the "infrastructure for development" of the countries must be strengthened, particularly in strategic sectors such as telecommunications and electricity. By the other hand, the universal access to electricity and telecommunications, are considered nowadays as basic factors of welfare and social equality. With this argumentation, the structural reforms about the 1980s promoted the resizing of State scope and encouraging private-enterprise participation. Over time, the most important criticisms of the economic model adopted during the eighties were its results, which, far from promoting equality, would have caused greater inequity. Then, some countries under populist governments, gone back to active state intervention in the economy, including sectors of public services among others the electrical and telecommunications. This phenomenon, during the last of 90 decade and beginnings of this century led to existence of two groups of countries in South America: by one side, countries with neo-populist governments (Argentina, Bolivia, Brazil, Ecuador, and Venezuela) and, on the other hand, countries that persisted with the reforms adopted during the eighties for to adopt market oriented economies (Chile, Colombia, Paraguay, Peru, and Uruguay), disparagingly named neo liberals by the early. The electrical and telecommunications sectors are considered pillars of the development and basic human right. Taking this on mind, one would expect that in the neo-populist governments, since its speech is based in a strong defense of poor population, should achieve higher levels of welfare than the liberal States, particularly in the infrastructure sectors named above. To prove this, in the present work, by comparing the general economic performance and particularly in both mentioned sectors between 2000 to 2015, through analysis of selected indicators it has been found quantitative evidence that those South American countries that are operating under the market model, have reached a better performance than the other ones. Furthermore, in both sectors under analysis, particularly in the telecommunications, it has been established that the first group countries (with neo-populist governments), the cost of access to services turns out to be more onerous than in those of the second group.
\end{abstract}

Keywords: Telecommunications, Electricity, Regulation, Economic Growth, Development, Economic Models

\section{Introduction}

Since the middle of the eighties and during the nineties, the structural adjustment and liberalization programs in Latin America (LA), were adopted. Under those development models, the private sector was designed as the main engine of the Bolivian economy. The role of public sector was reduced and reoriented towards economic regulation to infrastructure sectors such as telecommunications, electricity, sanitation, transportation, and hydrocarbons [1]. These reforms had two characteristics: 1) privatization processes, and 2) creation of new public entities with common characteristics in terms of their government mandate and some relationship with political power, as shown by [2] for Chile, Argentina, 
Bolivia, and Peru cases.

Years after, in Argentina, Bolivia, Brazil, Ecuador, and Venezuela, as a result of social dissatisfaction with the economic model emerged. This model change for many people perception, would have deepened the gap between the rich and poor population, giving raise strong neo populist movements with speeches related to radical revisions of the economic model. The assumption of the new governments in a group of countries, was preceded by bombastic welfare improvements announcements, as a result of deep adjustments in the economics through strong state intervention, in benefit of the less favored population. On the other hand, Chile, Colombia, Paraguay, Peru, and Uruguay, although they weren't free of these populist ideas, persisted in the market model, giving legal continuity to private investment.

This uncertainty situation in some countries and the stability of rules in other ones, offers us an interesting opportunity to test some theoretical economic postulates against the empirical evidence. Thus, based on the comparison of selected indicators of economy and telecommunications and electricity sectors, for both groups of countries, it has shown that the political use of discontent, has not allowed lay down foundations of economic development, as they promised. In this sense, the positive results observed at the beginning of neo-populist governments, seem to be more an effect of the circumstantial rising in raw materials prices than a statist's model advantage [3].

\section{Theoretical Framework}

In general, the impossibility of reach perfect competition in the markets is due to the failure of the two basic theorems of welfare economics. In this situation the need for public intervention arises, to imposing restrictions on the decisions making by economic agents. According to [4], market failures are not exceptions, but the rule, therefore the defense of markets through public intervention is appropriate as well.

As [5] and [6], among other, hold to guarantee that the criteria of economic efficiency as well as the competition, will be present in the markets, the government as the leading service provider and private sector must operate on it under the same rules, rights, and obligations that the privates. The politic reforms of the nineties were aligned to such fundamentals of economic theory.

Specifically, in public services, as [7] remarks, competition policies are the cornerstone of economic policy in a marketoriented economy. Therefore, it is not casual that during the privatizing wave, a large technical literature on economic regulation was generated. Some researchers as [8], have shown that to promote the competition and regulation is more appropriate than the state ownership strategy.

According to the economic literature, [9] and [10], among others, a Moral Hazard problem is present in marked public companies, due to imperfect control of the Owner State (Principal) and inadequate incentives for the managers of these government companies (Agents). These issues usually provoke a poor company's performance. In the same order, [11] show that due to this, state companies aren't listed on the stock markets and the State finances their eventual losses. Neither competition nor creditors, exercise a disciplinary role: the associated losses are covered -usually- by fiscal transfers. Likewise, the boards are politically appointed by the government and rarely apply good corporate governance practices.

Another mainstream research has focused on the interest of capitalizing politically the business management, which can lead to inefficient decisions. For instance, state enterprises become employment centers and mechanisms to reattribute or to grant favors without discretion. [12] shows that the State often exerts power beyond its shareholder rights, consequently, in companies with state participation there is a problem of ownership and control. On another side [13] conclude that the budget constraints of state-owned companies are lax, so they don't have incentives for searching efficient practices: it makes that the political cost for the government of an eventual bankruptcy of any public enterprise, isn't a credible threat.

\subsection{Crisis of Statist Model}

The strong entry of resources from the seventies led to LA to high indebtedness. According to [14], the magnitude of the external debt reached alarming magnitudes, the payments obligations, derived from external indebtedness, have exceeded the income of exports.

Until the crisis of the eighties, LA governments favored state ownership in strategic industries. The subjacent idea was that market failures deserved such a situation. However, the State owner-companies have poor performing, with lowquality production of goods and services, high costs and declining finances. Protected from competition, they provoked deficits, in some cases between $5 \%$ or $6 \%$ of GDP [1]. This, together with an assistance economic policy, was the cause of fiscal imbalances that characterized the crisis of those years.

The serious problems observed during the eighteen crises, required strategies to restore the macroeconomic equilibrium. Then, it becomes fashionable to compare the LA failure with the success of Southeast Asian countries to promote the opening markets [15]. In response, with the support of international organizations (e.g. IDB, WB, IMF), the governments, applied macroeconomic structural adjustment programs. For example, in Argentina, under the Alfonsín's (1983-1989) and Menem's (1989-1995) Governments, or in Bolivia under the Paz-Estenssoro's (1985-1989) and Sánchez de Lozada's (1993-1997) governments.

Under this panorama, the need to redirect capitals towards the region, made that the privatization option was looking like a necessary alternative. The first privatizations began in the mid of seventies in Chile, as a response to the expropriations carried out by the Salvador-Allende's government (1970 - 1973). In other countries, massive privatizations took place at the end of the eighties, as part of 
a new economic model. However, the sectors and processes of privatization weren't the same: Bolivia, Chile, México, and Nicaragua State owner enterprises of competitive sectors such as manufacturing and finance, were privatized first, and later monopolies companies of public service. Argentina, Brazil, Colombia, and Peru sold both types of companies simultaneously. In Argentina and Bolivia, to maximize revenues, the monopolistic structure was maintained, even in sectors where technology enabled greater competition. In sanitation, transport infrastructure and oil exploration and production, some concession contracts were used to grant operating rights [1].

The structural reforms in LA were accompanied by extensive privatization programs. This implied, between years 1990-1999, revenues for the States of almost 180 billion dollars (showed in Figure 1), almost like 1\% of regional GDP, the double of average of other regions [16].

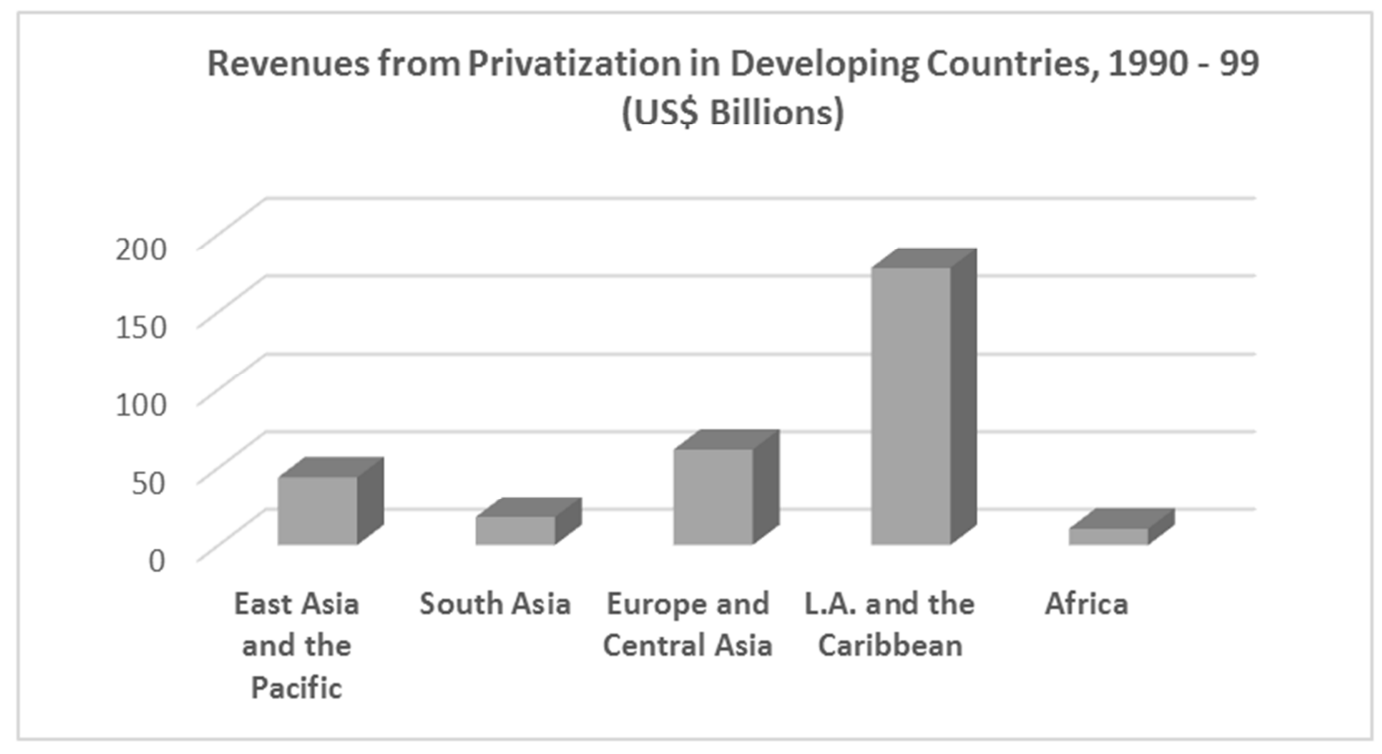

Source: Adapted from [17]

Figure 1. Revenues from privatization in developing countries, 1990-99.

\subsection{The State as Regulator}

Regarding economic theory as the previously cited articles, for example, Newman [7] or [5] to name a few, in absence of failures, the dynamics of market guarantees efficient but not necessarily equitable results. In this sense, regulation should be oriented to simulate conditions of competency as well as searching mechanisms to increase access to basic services. Leaving the market as the only allocation resources mechanism and neglect access issues, could mean that, in the short term, the introduction of competition be negatively perceived. For this reason, market-oriented economic policies must be accompanied by a regulatory framework, to guarantee, among others but as one of the important objectives, access to basic services by the poorest population.

In absence of an appropriated legal framework, it has been observed in many examples, failed privatization. Because of inadequate regulation that took the competition to sub-optimal levels, income transfers from consumers to producers take place [1].

Good regulatory design implies institutionality and regulatory governance. For this, a complete regulatory framework and a regulatory body well trained, independent, impartial and equidistant between the State, society and the company, are necessaries. The regulator State does not substitute the market, but through the establishment and application of certain conduct codes, seeks similar results than those the market produces. An adequate regulation code encourages the market functioning and focuses on the strengthening of institutional capacities, for example, the information asymmetry reduction [17].

\section{Methodological Proposal}

The neo populism is a term used to designate to the resurgence of the populist current in Latin America, after the dictatorships of the eighties in the region. For typify or not as neo populist to the governments, supported in the works of $[18,19]$ and [20], some common features of left populism or neo-populism, for the period of analysis have been identified in five LA countries, the results are shown in table 1.

According to the results of Table 1, in this research have been identified two groups of countries', based on their recent behavior. The first of them (Group 1), integrated by Argentina, Bolivia, Ecuador, Brazil, and Venezuela, are those where neo-populism took the government during the period analyzed. The second one (Group 2) involves the Colombia Chile, Peru, Paraguay, and Uruguay countries, are those that do not any economic model change did. 
Table 1. Characterization of Neo-populism.

\begin{tabular}{|c|c|c|c|c|c|}
\hline Country & $\begin{array}{l}\text { Popular will embodied } \\
\text { in the charismatic } \\
\text { leader }\end{array}$ & $\begin{array}{l}\text { Is Authoritarian and } \\
\text { discretional in use of } \\
\text { public resources }\end{array}$ & $\begin{array}{l}\text { Exacerbates } \\
\text { antagonisms between } \\
\text { rich and poor }\end{array}$ & $\begin{array}{l}\text { Exacerbates } \\
\text { nationalist and anti- } \\
\text { imperialist sentiments }\end{array}$ & $\begin{array}{l}\text { Advocates an anti- } \\
\text { neoliberal policy }\end{array}$ \\
\hline Argentina & $v$ & $v$ & $v$ & $\mathrm{v}$ & $\mathrm{v}$ \\
\hline Bolivia & $v$ & $v$ & $\mathrm{v}$ & $\mathrm{v}$ & v \\
\hline Brazil & $v$ & $\mathrm{v}$ & v & v & v \\
\hline Ecuador & $v$ & $v$ & $\mathrm{v}$ & $\mathrm{v}$ & $v$ \\
\hline Venezuela & v & v & V & v & v \\
\hline
\end{tabular}

Source: Own elaboration

To understand the changes and expectations generated into the Group 1 countries, a general and succinct analysis is developed according to the circumstances of the processes of coming back to the statist model. Likewise, with the help of economic and sectoral indicators, a comparative analysis between both groups of countries is completed. This approach allows to obtain empirical evidence and signals related to economic and social performance according to the type of economic model of each group of countries.

There are several methodologies to analyze the performance of an economy and a non-closed discussion with strong ideological content.

In this case, we objectively attempt to show whether the countries of Group 1 or Group 2 present better economic results. Two levels of analysis have been defined using macroeconomic and price indicators as well as specific indicators of telecommunications and electricity sectors.

\subsection{Macroeconomics Indicators}

The growth rate of Gross National Product (GNP) is an indicator commonly used to measure the economic growth. Likewise, the Consumer Price Index (CPI) allows appreciating economic stability and market predictability. Stable values of these indicators allow better predictability and planning; however, erratic values exacerbate the risk aversion and the cost of uncertainty.

On the other hand, in LA countries, the structural deficit of savings, from the public sector, becomes the private initiative and foreign investment a necessary complement to boost the economy. In this sense, the appropriate environment or the simplicity and security of legal and administrative procedures, allow stronger private and foreign presence in the economy.

\subsection{Telecommunication and Electricity Sectors Indicators}

These sectors have been selected, because i) both are a pillar of economic and social development and an efficient performance of them, implies achieve greater social welfare, ii) access to electricity is a sine qua non-condition for equity, and iii) both services are considered human rights

Electricity and telecommunications are basic services that nowadays are considered a human right [21, 22], and consequently, have been used as a measure of welfare. Also, high levels of access to high-quality services are characteristic of countries with superior economic and social development, and in turn, allow greater growth capacity. One of the largest barriers to access is undoubtedly the cost of those services.

In general, structural changes made by neo-populist governments, have been justified with a promise to improve access to better services, so it is important to know what has happened in these core sectors.

\section{Coming Back to the Statism - the Neo-populism}

Although the researchers have shown that the privatization process developed during the $80 \mathrm{~s}$ and $90 \mathrm{~s}$ had important positive balances, the perception of negative results prevailed to promote political changes in the countries of Group 1. [23] seeking an answer to why the disagreement with privatization, despite its positive results in the Bolivian case, after analyzing the sectors such as public health and electricity, conclude that, in those countries with high poverty, the State must be a direct actor in the development of infrastructure for the provision of basic services to avoid the negative popular perceptions against the private provision of public services.

[24] points out that public management should guide public policies. Thus, the government institutions must have adequate instruments for control and evaluation of public actions. Faced with growing socio-political discontent, he points out that the control of public management seen as a continuous improvement process (plan-do-verify-act), would have made possible better visibility of results.

The perception that the privatization or neoliberal model was not beneficial, together with a strong anti-market feel on popular sectors, was capitalized by so-called Socialism of 21 st Century to achieve the reversion of privatization, particularly in countries members of Americas' Bolivarian Alliance - ALBA [23]. From the economic perspective, the debate on economic growth and human development has once again become valid. In this sense, [25] points out that economic growth is required, based on certain investment conditions, to achieve higher levels of development with equity. This reasoning has served to materialize political processes of structural changes in some countries of South America.

A quick review of context and the actions assumed by the countries of Group 1 during the analyzed period, shows the existence of common elements in the structural changes, adopted towards to come back to the statist model. 


\subsection{Venezuela}

The electoral triumph of Hugo Chávez in 1998, was the result of the exhaustion of economic-social model in force in Venezuela. Chavez was able to convey a message of change, canalizing popular dissatisfaction. His speech (Bolivarian Revolution) was perceived as a real alternative to the deterioration process of capital-labor relationship [26].

Under the promise of calling a National Constituent Assembly for State reestablish social justice, Hugo Chávez captivated popular sentiments with a discourse of democratic deepening and rejection of the neoliberal model. Chávez began raising the need to fight against neoliberalism and later, it was radicalized until to set the need to create a new political current, named, Socialism of the XXI Century. The Transition Program (1999-2000), had among its pillars, a centralized economy and the nationalization of telecommunications as wells as electricity companies, among others strategic services. Under this model, private participation in strategic sectors was subordinated to the aims and control of the State [27].

\subsection{Bolivia}

Between 2000 and 2004, Bolivia has experienced a period of deep political instability and internal convulsion. In this stage, Bolivia had three presidents in only four years: First Gonzalo Sánchez de Lozada (2002-2003), winner of the national elections of 2002, who had to be constitutionally succeeded by his Vice President Carlos Mesa (2003-2005), because of the popular pressure. In Mesa's period, the country reached a level of conflict never seen before. After Eduardo Rodriguez Veltze, the Supreme Court of Justice President, assumed the government by constitutional succession in the middle of a political crisis without precedents, with a transition government in charge of to convene general elections in the next six months.

The political instability reached ended when, in December 2005, Evo Morales won the national elections. Among his electoral promises, Morales proposed to eliminate of the regulatory system and revert of capitalization [23]. Morales breaks with the market model through revert to State the control of the privatized companies and affecting the reforms implemented since the nineties.

With the call to Constituent Assembly (August 2006 December 2007), Morales was searching to put an end to a State that, according to his ideological line, was replying to the abuses of the colony against indigenous peoples [28]. This process was accompanied by a high uncertainty degree, due to the contradiction between Morales' discourse about the respect of the private property and the violent takeover of privatized companies.

\subsection{Ecuador}

Rafael Correa was elected Ecuador president in 2006 (2007-2017). By then he had no political career, most of his professional life was spent in the private sector and the academic environment. His publications highlight a rejection of neoliberalism and the economic policies of his predecessors [29]. The socialism advocated by Correa has a foothold in Christianity and not in Marxism, but he declares himself openly adept at the so-called Socialism of the $21 \mathrm{st}$ Century. Correa prepared the call for a constituent assembly his most visible government proposal and his speech turned against the traditional political parties.

[30] points out that the economic policy of Correa's government seeks to revert the liberal economic model with strong State participation in the economy. Consequently, public investment has become the fundamental pillar of growth in these years and the private participation was subordinated to government policies.

\subsection{Argentina}

In Argentina, the social consequences of the crisis were enormous: open unemployment went from $15 \%$ in 1998 to $21.5 \%$ in 2002 ; the average real wage fell more than $23 \%$; the middle class was devastated by the fall in the income of employees and retirees, the dispossession of savings (called "corralito") and the deposits in foreign currency were converted into national currency. The poor population rose to more than $50 \%$. From being one of the most egalitarian societies in Latin America, it became one of the most unequal societies [31].

With the rise of Kirchner to the presidency (2003-2007), the country grew at an annual rate of around 8 to $9 \%$ and a process of reindustrialization took place. Thanks to the popularity and audacity of its first measures (renewal of the military and police leadership and the Supreme Court of Justice, ignorance of the impunity laws for genocidal militaries, etc.), Kirchner achieved the highest popularity ratings of a president in Argentina [32].

In the social sphere, Kirchner extended the coverage of the retirement system and the welfare subsidy to unemployment and resumed the consensual fixation of the minimum wage. The government opposed the criminalization and repression of protests and internationally, its most notorious measures were the diplomatic recognition of Cuba, the revitalization of Mercosur and the rejection of the Free Trade Area of the Americas - ALCA [32].

\subsection{Brazil}

In October 2002, Luiz Inácio Lula da Silva (2003-2010), was presented for the fourth time in the Presidential elections of the Federative Republic of Brazil, defeating in the second round to candidate of Brazilian Social Democracy. To achieve this, Lula proposed a social pact that he called "living forces of the Nation". After his victory in 2002 elections, there was great uncertainty regarding the type of economic policy that his government will adopt, because although during the campaign Lula stressed his commitment to maintaining the country's economic stability, it was feared that he would not resist the pressure of sectors of Workers' Party to make economic changes that put it in risk.

With Lula, changes were promoted seeking to get people 
out of extreme poverty: agrarian reform, job training, cooperative movement, family farming. In his second mandate (2007-2010), the need to achieve greater income distribution was raised: the maintenance of social plans including the Zero Hunger Plan and the agrarian and tax reform [33].

\section{Compared Analysis}

The preceding review shows, particularly in five L.A. countries, a credibility crisis about the kindness of the market model. The solution adopted was conditioned by the own political, economic and social history of each country. However, there are also common features, mainly by the economic model adopted and by the messages sent to the market. Both features are the motivation for this exploratory analysis. For example, a common feature in the five countries is the rise of neo-populist governments, which take the power with strong attacks to market model and with promises of deep structural modifications, affecting mainly over private rights, especially the foreign investments.

From the perspective of the Contracts Theory $[9,34]$ in the five cited cases, the uncertainty periods traversed, because of regulatory changes and ownership affectation, the contract was modified. For example, in Bolivia, with the so-called nationalizations and with the elimination of the regulatory system; in Argentina, through the freezing of product prices and service tariffs, among others.

Next, the effects caused by this uncertainty period are examined. Our interest focuses on telecommunications and electricity sectors, because the privatization and structural reforms in the previous period were preceded by structural changes in the rules oriented to guarantee legal security for private investment in both sectors. According to this, State participation in the economy ought on equal terms with the private ones, and an impartial and independent regulatory institutionality, ought to be who judge the conduct in the market of all agents.

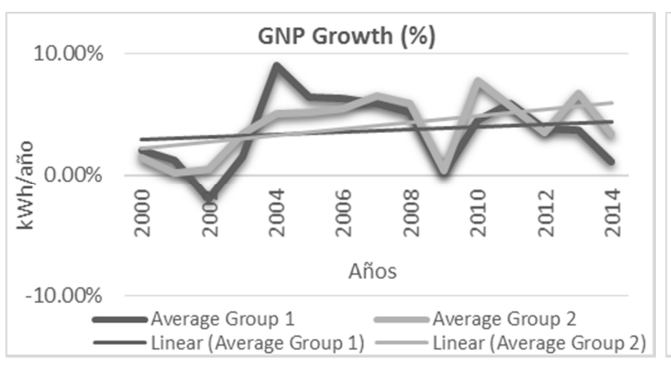

Source: Own preparation with information from the [35].

Figure 2. Percentage Growth in percentage and Weighted growth in percentage GNP.

To eliminate the bias caused by economies size, the applied indexes have been corrected by the relative size of GNP. In this case, volatility is even more pronounced in both groups (see in the graph at the bottom of the of Figure 2), engaging the largest economies in each group have had greater volatility, but the countries in Group 1 have experienced greater turbulence in their economies. Despite

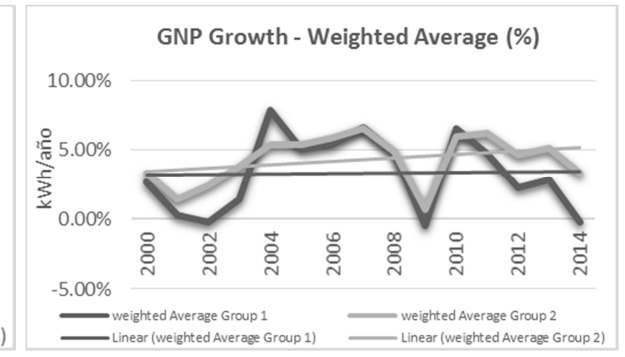

The analysis is carried out by comparing some macroeconomic and sectorial indicators (to telecommunications and electricity), between the two groups of countries. Group 1 integrated by Argentina, Bolivia, Brazil, Ecuador and Venezuela, which have as common characteristics the neo-populism and the structural changes oriented to increase state intervention, particularly in infrastructure sectors. Group 2, despite its leftwing government's profiles - in Chile, the rulers that after 1990 succeeded A. Pinochet, in Uruguay J. Mujica (2010 - 2015) and Peru O. Humala (2011 - 2016) -, none of the rules of the games were affected.

With this comparison, we intend to comprehend the effect that these situations would have had on the performance of those economies, and in the telecommunications and electricity sectors.

On one hand, following the established by economic theory, for example [4], the threat of unilateral break of the game's rules, generates instability and uncertainty and, therefore, changes in investment decisions. On the other hand, given the private administration privileges economic results, this could lead to greater inequality, as has been perceived by the promoters of the structural changes implemented in Group 1 countries.

\subsection{Macroeconomics Behavior}

The analysis of Gross National Product Growth - GNP, Inflation - IPC and Gross Capital Formation - FBK, shows interesting results. A priori and without another type of considerations based on economic theory, it might expect that the growth of an economy with strong state intervention to be less volatile, as a result of centralized planning. However, this is not verified in the present case, thus, between 2000 and 2014, as can be seen in the graph at the top of Figure 2, economic growth on Group 1 countries has fluctuated more than that Group 2 countries. Likewise, the trend line shows that Group 1 countries, contrary to what is appreciated for Group 2, would have in perspective little decreasing growth rates over time.

this adjustment, Group 1 keep going showing a decreasing tendency in their GNP growth rate.

As is known, inflation is a fundamental variable for analyzing economies and their predictability. The inflation analysis shows that Group 1 countries have had higher and even explosive growth inflation levels during the entire period (see Figure 3). This is verified both using indicators 
without any adjustment and indicators corrected by the

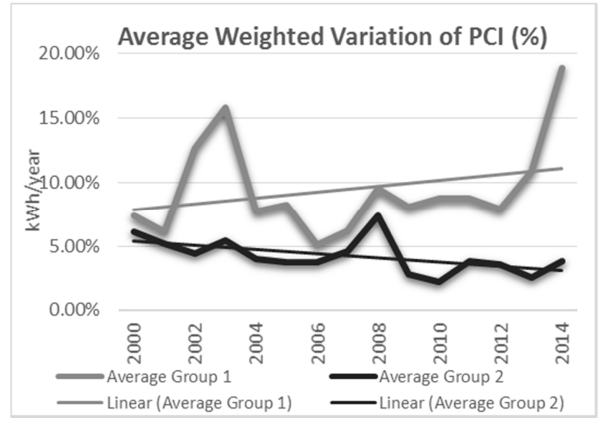

relative size of its economies.

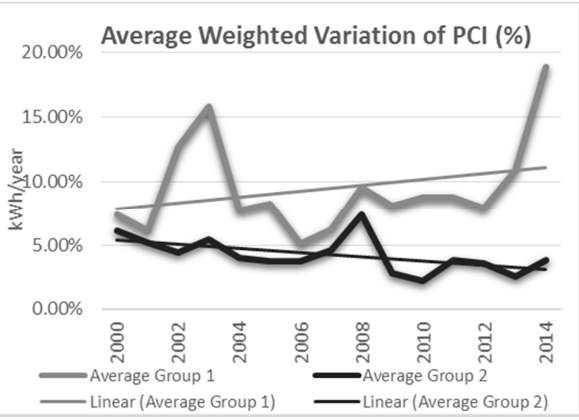

Source: Own preparation with information from the [35]

Figure 3. Variation and Weighted Variation of PCI.

With erratic changes in prices and/or rising inflation, more uncertainty is generated, and it is expected that investment slows down; therefore, with the higher price volatility in Group 1 countries, the investment should be lower than Group 2 countries. To verify this, the behavior of gross capital formation (FBK) as a percentage of GNP has been analyzed with both groups. However, the results of the comparison do not allow us to conclude that this would have occurred (see Figure 4), although it could be due to the substitution of private investment by state ones. But when the analysis is made from weighted averages it is established that this has been less important in Group 1 countries.
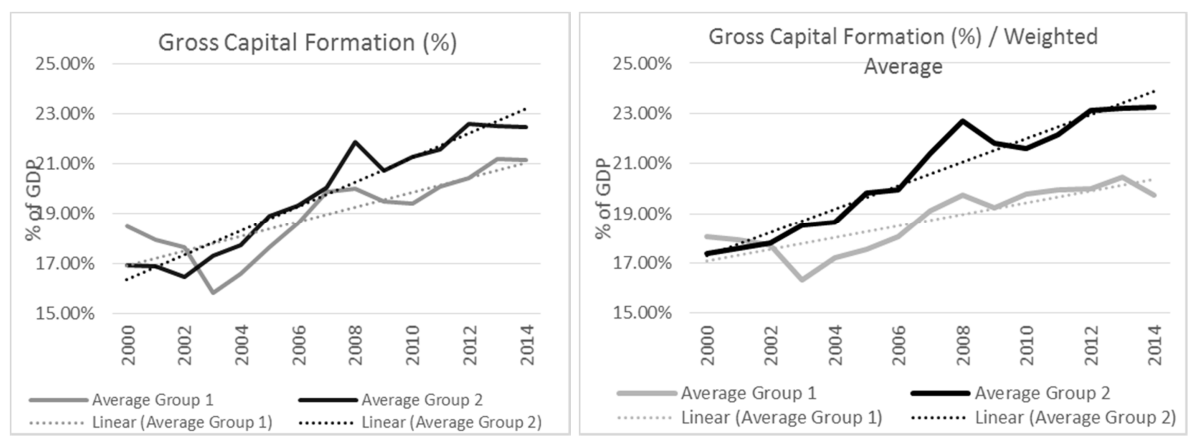

Source: Own preparation with information from the [35]

Figure 4. Gross Formation of Capital.

Due to the savings structural deficit in the developing countries and the weakness of public finances, the contribution of the foreign investment and national private sector to the economy is an undeniable necessity, but it depends on the prevailing business climate. In this sense, with the information generated by the World Economic Forum (WEF), an analysis of the economic-business climate in the South American countries has been made, also incorporating a reference country (United States of America). This inquiry also yields important findings.

Three indicators have been analyzed: i) the percentage of the total tax rate, defined as the sum of the percentage rates of all taxes and social / labor charges that are applied to companies, ii) the number of days that is delayed in average, the establishment of business, and iii) the number of procedures that must be carried out to establish a business. The trends results have shown in Figure 5. In the Group 2 countries and the reference country, the percentage of total tax rate is less than $50 \%$, while in Group 1 countries, it is above $75 \%$. As higher is this percentage greater is the state appropriation of the result of the company and less attractive are the business.
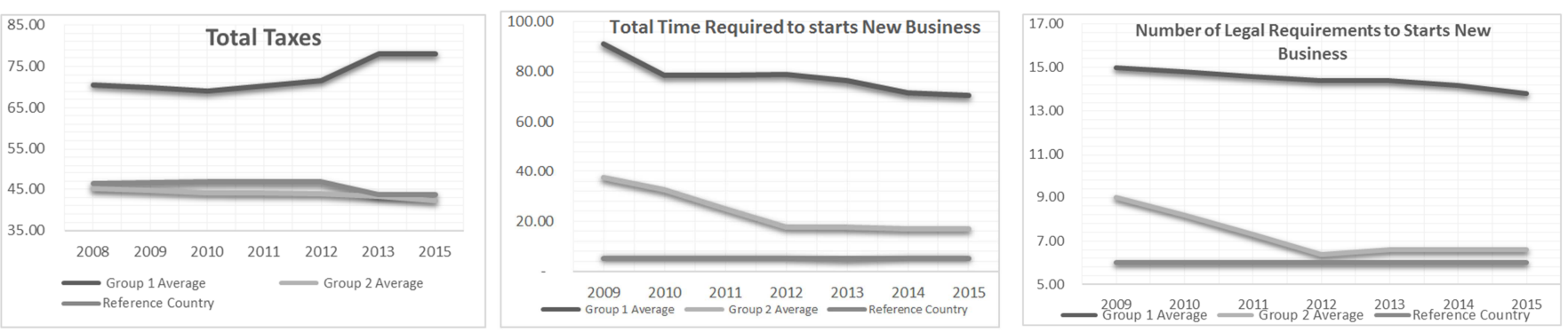

Source: Own preparation with information of [36]

Figure 5. Business Environment. 
In the upper right part of Figure 5 it can be seen that in Group 1 countries, it takes, on average, more than 70 days to complete the legal requirements for a new business, by the opposite in Group 2 countries it takes less than 20 days, although, compared to the reference country, this is still a very long time.

The conclusion is that in Group 1 countries, to establish a business, twice as many procedures must be fulfilled as in Group 2 countries, and in the latter countries, the number of procedures is slightly higher than in the reference country (USA).

The research shows that making private ventures (entrepreneurship) in South America is more complicated than in developed countries, but it is even more complicated in Group 1 countries. Seen this way, the private's ventures in the Group 1 countries faces notoriously more complex environment troubleshooting than Group 2 countries, characterized by confiscatory tax regulations and bureaucracy that discourage the setting up of new business and entrepreneurship.

\subsection{Telecommunications Sector Behavior}

The telecommunications sector, thanks to the explosive development of technology, is currently seen with special interest. Today, its role as a promoter of economic development is undeniable. For example, it has been observed that countries where Broadband penetration has grown by $10 \%$, have experienced an increase of $3.19 \%$ in GDP, an increase of $2.61 \%$ in their productivity and a new generation of more than 67,000 jobs [37]. The [38], establishes that small and medium enterprises with intensive use of the Internet improved their productivity by $10 \%$ in sales and cost savings, as well as their business relationships, grew twice as fast.

As [37] states, there is evidence to affirm that Internet is a powerful tool to prop up economic growth and to improve the distribution of income. Therefore, it is particularly important to carefully observe the governments' perception of the role of the telecommunications have in economic development, for adoption of challenging policies related to Information and Communication Technologies (ICT).

About this context, the World Economic Forum (WEF) has developed indicators to show the degree of involvement and importance that governments grant to ICTs in their respective plans. The first indicator "Laws related to ICT", shows on a scale of 1 (nonexistent) to 7 (well developed), the assessment of the use of ICT; the second "Importance of ICT for the vision of future", shows to what extent the government have a clear plan of application and use of ICT to improve global competitiveness in a scaled assessment of 1 (nonexistence of plan) to 7 (robust plan). Figure 6 shows the comparison of both groups of countries regarding these indicators.

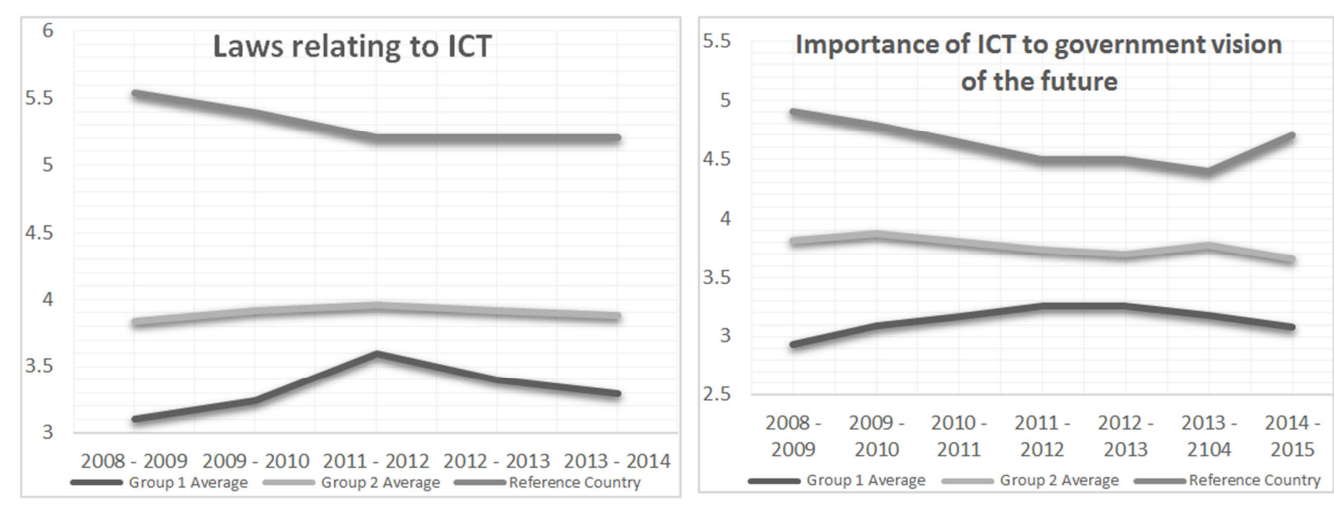

Source: Own preparation with information of [36]

Figure 6. Importance of ICT for the Governments.
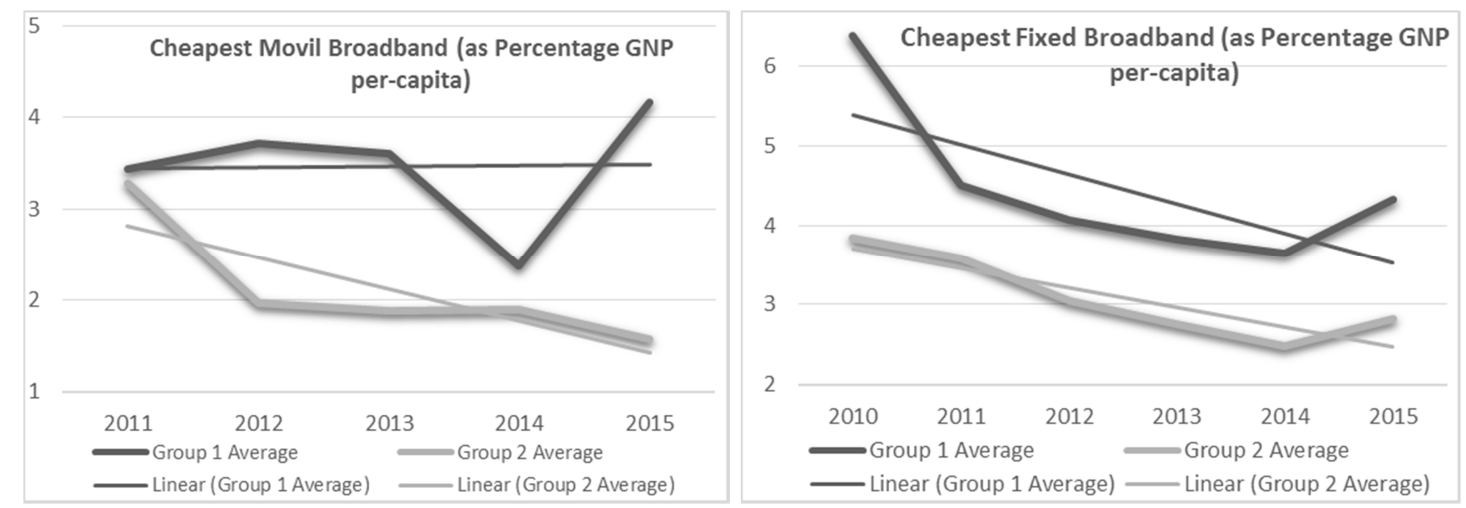

Source: Own preparation with information of [39]

Figure 7. Relative Cost of Broadband Access. 
On the other hand, an important barrier to access at any services are its tariff of provision. In this sense, the policies of the States should be directed toward attacking these barriers, among other measures.

It is interesting to see how the reference country has close to level 7, while the South American countries are well below this ideal value. Worse still, the countries in Group 1 seem not to perceive ICT as a key ally to improve productivity and competitiveness.
Equally important, from the information published by the Regional Dialogue Organization on the Information Society [39], it can be seen (see Figure 7) that both mobile broadband and fixed broadband plans are more expensive in countries of Group 1 .

Likewise, in Figure 8, it is shown that Group 1 countries have a slightly lower percentage of Internet connections than those of Group 2 ones.

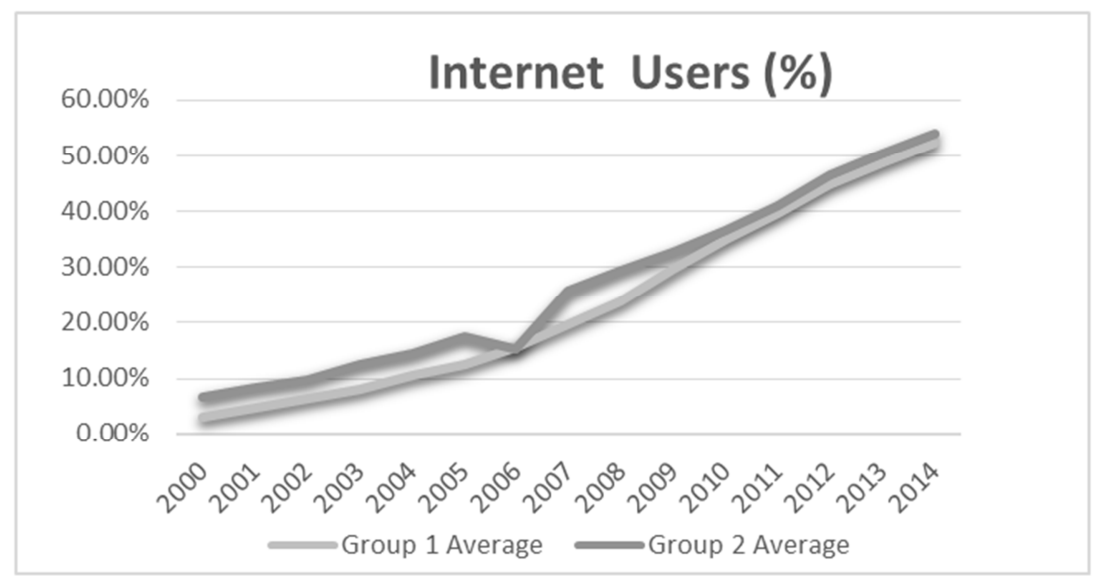

Source: Own preparation with information of [35]

Figure 8. Broadband access.

Private investments in telecommunications have a decreasing trend in Group 1 countries; while in Group 2 countries had remained practically constant as a proportion of GDP (see Figure 9).

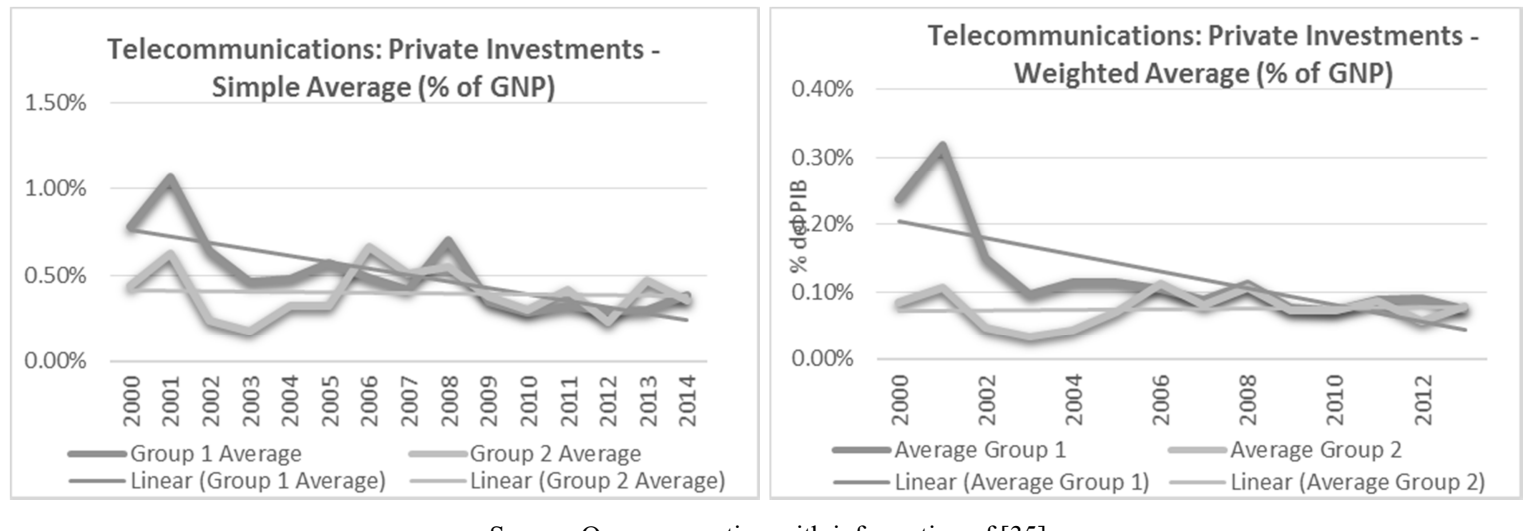

Source: Own preparation with information of [35]

Figure 9. Private Investments in Telecommunications.

These results, analyzed as weighted averages, show a more dramatic situation for Group 1.

The analyzed results show that Group 1 countries: i) don't seem to consider telecommunications as a fundamental development factor, and in particular, ii) they don't consider important the contribution of the private sector, iii) they show important barriers to ICTs access, and, as a consequence, iv) they have Internet access levels lower than Group 2 countries. These findings do not seem to be favorable to achieve the commitments of Millennium Development Goals ${ }^{1}$.

\subsection{Electric Sector Behavior}

Achieving improvements in electricity coverage is one challenge imposed by governmental agendas, according to the undeniable relationship between social welfare and the provision of electricity. In this sense, the reforms practiced in the nineties mainly implied, among other reasons, the vertical disintegration: a competitive market in power generation,

upon for 2015 by the 189 member countries of the United Nations in the year 2000. To fulfill these goals, telecommunications and electricity coverage are fundamental pillars. 
regulated markets in both transmission and distribution as wells as an independent regulator of agents' activity. All the above, to achieve greater operational efficiency in the power sector. The achievement of $100 \%$ coverage also is a fundamental part of the millennium goals.

The electricity sector has been characterized by technological changes to improve energy efficiency and better use of renewable energies, forced by the gradual depletion of conventional energy sources, high oil prices and searching clean energy sources.

Figure 10 shows that the coverage in both groups of countries is above 97\%, although slightly higher in the countries of Group 1 (see graph on the right side). The left part of the same Figure 10 shows that per capita consumption has been increasing steadily and by 2013 both groups have a similar consumption, although with a slight advantage in favor of Group 1 countries, which probably is explained by distortion of electricity prices in these countries.

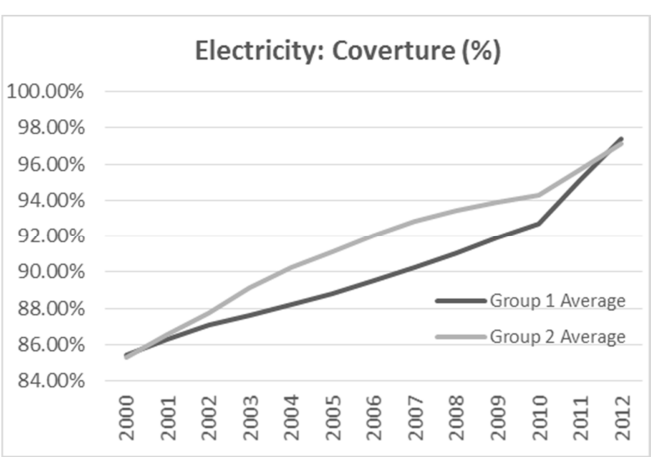

Source: Own preparation with information of [35]

Figure 10. Per-capita consumption and Electric Covertures.

However, when other qualitative indicators are analyzed, the differences arise. Losses are a typical measure of operational efficiency, Figure 11 on the left side can be seen that electrical system losses are notably higher in Group 1 countries. Likewise, on the right side if this figure 11, Private investments in Group 1, have practically disappeared, on the contrary in Group 2 countries, they are the main source of the financing expansion sector.

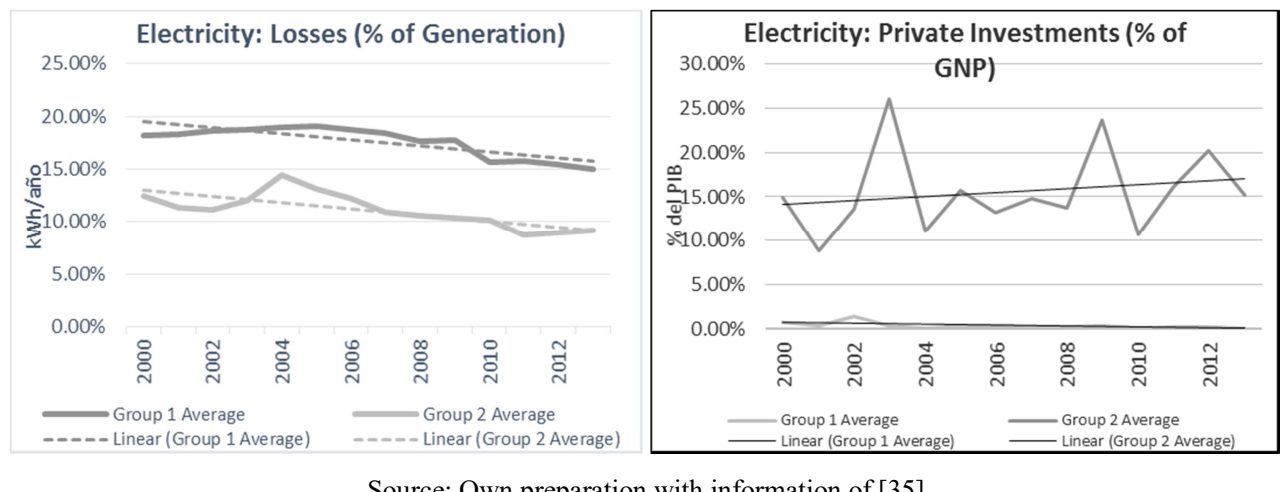

Source: Own preparation with information of [35]

Figure 11. Losses of the System and Private Investments on Electricity.

Countries such as Bolivia and Venezuela, through policy signals, regulatory decisions, and/or issuance of new regulations, have concentrated the enterprises in the State, and the economic features have ceased to be making-decision criteria. For instance, in the Bolivian case, the government program establishes that by $2025,100 \%$ coverage must be achieved; to achieve this objective, companies also must make investments in expansion to increasingly remote rural communities, although the economic return be negative.

\section{Discussion of Results}

\subsection{Economic Environmental}

The economic context has been analyzed through many indicators, such as: i) economic growth, ii) inflation, iii) gross capital formation, iv) total tax rate, v) time to set up a business, and vi) the number of procedures required to achieve it.

Group 1 shows the worst situation in relation with the economic performance. The higher volatility of economic growth is corroborated by looking at the average standard deviation, which in the case of Group 1 reaches 4.39 (2.95 if is considered the averages), and in the case of Group 2 at 3.41 (2.49 if is considered the averages). Largely, this greater deviation is explained by Argentina, Brazil, and, mainly, Venezuela; since Bolivia and Ecuador show more stable growth rates, as can be seen in Table 2 (highlighted grey). 
Table 2. Annual Growth of GNP by Countries (\%).

\begin{tabular}{|c|c|c|c|c|c|c|c|c|c|c|c|c|}
\hline YEAR & Argentina & Bolivia & Brazil & Ecuador & Venezuela & $\begin{array}{l}\text { Average } \\
\text { Group } 1 \\
\end{array}$ & Chile & Colombia & Paraguay & Perú & Uruguay & $\begin{array}{l}\text { Average } \\
\text { Group } 2 \\
\end{array}$ \\
\hline 2000 & $-0.80 \%$ & $2.50 \%$ & $4.10 \%$ & $1.10 \%$ & $3.70 \%$ & $2.12 \%$ & $4.50 \%$ & $4.40 \%$ & $-2.30 \%$ & $2.70 \%$ & $-1.90 \%$ & $1.48 \%$ \\
\hline 2001 & $-4.40 \%$ & $1.70 \%$ & $1.70 \%$ & $4.00 \%$ & $3.40 \%$ & $1.28 \%$ & $3.30 \%$ & $1.70 \%$ & $-0.80 \%$ & $0.60 \%$ & $-3.80 \%$ & $0.20 \%$ \\
\hline 2002 & $-10.90 \%$ & $2.50 \%$ & $3.10 \%$ & $4.10 \%$ & $-8.90 \%$ & $-2.02 \%$ & $2.20 \%$ & $2.50 \%$ & $0.00 \%$ & $5.50 \%$ & $-7.70 \%$ & $0.50 \%$ \\
\hline 2003 & $8.80 \%$ & $2.70 \%$ & $1.10 \%$ & $2.70 \%$ & $-7.80 \%$ & $1.50 \%$ & $4.00 \%$ & $3.90 \%$ & $4.30 \%$ & $4.20 \%$ & $0.80 \%$ & $3.44 \%$ \\
\hline 2004 & $9.00 \%$ & $4.20 \%$ & $5.80 \%$ & $8.20 \%$ & $18.30 \%$ & $9.10 \%$ & $6.00 \%$ & $5.30 \%$ & $4.10 \%$ & $5.00 \%$ & $5.00 \%$ & $5.08 \%$ \\
\hline 2005 & $9.20 \%$ & $4.40 \%$ & $3.20 \%$ & $5.30 \%$ & $10.30 \%$ & $6.48 \%$ & $5.60 \%$ & $4.70 \%$ & $2.10 \%$ & $6.30 \%$ & $7.50 \%$ & $5.24 \%$ \\
\hline 2007 & $8.00 \%$ & $4.60 \%$ & $6.10 \%$ & $2.20 \%$ & $8.80 \%$ & $5.94 \%$ & $5.20 \%$ & $6.90 \%$ & $5.40 \%$ & $8.50 \%$ & $6.50 \%$ & $6.50 \%$ \\
\hline 2008 & $3.10 \%$ & $6.10 \%$ & $5.10 \%$ & $6.40 \%$ & $5.30 \%$ & $5.20 \%$ & $3.30 \%$ & $3.50 \%$ & $6.40 \%$ & $9.10 \%$ & $7.20 \%$ & $5.90 \%$ \\
\hline 2009 & $0.10 \%$ & $3.40 \%$ & $-0.10 \%$ & $0.60 \%$ & $-3.20 \%$ & $0.16 \%$ & $-1.00 \%$ & $1.70 \%$ & $-4.00 \%$ & $1.00 \%$ & $4.20 \%$ & $0.38 \%$ \\
\hline 2010 & $9.50 \%$ & $4.10 \%$ & $7.50 \%$ & $3.50 \%$ & $-1.50 \%$ & $4.62 \%$ & $5.80 \%$ & $4.00 \%$ & $13.10 \%$ & $8.50 \%$ & $7.80 \%$ & $7.84 \%$ \\
\hline 2011 & $8.40 \%$ & $5.20 \%$ & $3.90 \%$ & $7.90 \%$ & $4.20 \%$ & $5.92 \%$ & $5.80 \%$ & $6.60 \%$ & $4.30 \%$ & $6.50 \%$ & $5.20 \%$ & $5.68 \%$ \\
\hline 2012 & $0.80 \%$ & $5.10 \%$ & $1.90 \%$ & $5.60 \%$ & $5.60 \%$ & $3.80 \%$ & $5.50 \%$ & $4.00 \%$ & $-1.20 \%$ & $6.00 \%$ & $3.30 \%$ & $3.52 \%$ \\
\hline 2013 & $2.90 \%$ & $6.80 \%$ & $3.00 \%$ & $4.60 \%$ & $1.30 \%$ & $3.72 \%$ & $4.20 \%$ & $4.90 \%$ & $14.00 \%$ & $5.80 \%$ & $5.10 \%$ & $6.80 \%$ \\
\hline
\end{tabular}

Source: Own preparation with information of [35]

In particular, it is the strong crisis that affects Venezuela and Brazil which leads this group towards a marked downward trend in its economic growth rates. In Group 2, the greater stability is explained by the behavior of the economies of Chile, Colombia, and Peru, because they are the most important economies in this group. Notoriously, these countries have shown a greater commitment with the liberal economy.

Table 3 displays the inflation breakdown by country for the period 2000 to 2015. Inflation has a quite similar explanation to that of economic growth. The inflation standard deviation observed, in the case of Group 1, rises to
14.85 ( 7.36 when is considered the averages), while in the case of Group 2 it reaches 3.40 ( 1.59 when is considered the averages).

The highest rates of inflation in the case of Group 1 occur in Venezuela and Argentina with rates above $100 \%$ and $40 \%$, respectively. It is important to highlight that all the countries in this group have had at some point inflation rates higher than those experienced by Group 2 countries, although Argentina, Venezuela and more recently Brazil have experienced greater turbulence. In Group 2, the largest economies (Chile, Perú, and Colombia) have maintained inflations below $10 \%$ per year, frequently, with rates of less than $5 \%$.

Table 3. Annual Inflation by Countries.

\begin{tabular}{|c|c|c|c|c|c|c|c|c|c|c|c|c|}
\hline YEAR & Argentina & Bolivia & Brazil & Ecuador & Venezuela & $\begin{array}{l}\text { Average } \\
\text { Group } 1\end{array}$ & Chile & Colombia & Paraguay & Peru & Uruguay & $\begin{array}{l}\text { Average } \\
\text { Group } 2 \\
\end{array}$ \\
\hline 2000 & $-0.90 \%$ & $4.60 \%$ & $7.00 \%$ & $96.10 \%$ & $16.20 \%$ & $24.60 \%$ & $3.80 \%$ & $9.20 \%$ & $9.00 \%$ & $3.80 \%$ & $4.80 \%$ & $6.12 \%$ \\
\hline 2001 & $-1.10 \%$ & $1.60 \%$ & $6.80 \%$ & $37.70 \%$ & $12.50 \%$ & $11.50 \%$ & $3.60 \%$ & $8.00 \%$ & $7.30 \%$ & $2.00 \%$ & $4.40 \%$ & $5.06 \%$ \\
\hline 2002 & $25.90 \%$ & $0.90 \%$ & $8.50 \%$ & $12.50 \%$ & $22.40 \%$ & $14.04 \%$ & $2.50 \%$ & $6.40 \%$ & $10.50 \%$ & $0.20 \%$ & $14.00 \%$ & $6.72 \%$ \\
\hline 2003 & $13.40 \%$ & $3.30 \%$ & $14.70 \%$ & $7.90 \%$ & $31.10 \%$ & $14.08 \%$ & $2.80 \%$ & $7.10 \%$ & $14.20 \%$ & $2.30 \%$ & $19.40 \%$ & $9.16 \%$ \\
\hline 2004 & $4.40 \%$ & $4.40 \%$ & $6.60 \%$ & $2.70 \%$ & $21.70 \%$ & $7.96 \%$ & $1.10 \%$ & $5.90 \%$ & $4.30 \%$ & $3.70 \%$ & $9.20 \%$ & $4.84 \%$ \\
\hline 2005 & $9.60 \%$ & $5.40 \%$ & $6.90 \%$ & $2.40 \%$ & $16.00 \%$ & $8.06 \%$ & $3.10 \%$ & $5.00 \%$ & $6.80 \%$ & $1.60 \%$ & $4.70 \%$ & $4.24 \%$ \\
\hline 2006 & $3.40 \%$ & $4.30 \%$ & $4.20 \%$ & $3.00 \%$ & $13.70 \%$ & $5.72 \%$ & $3.40 \%$ & $4.30 \%$ & $9.60 \%$ & $2.00 \%$ & $6.40 \%$ & $5.14 \%$ \\
\hline 2007 & $8.80 \%$ & $8.70 \%$ & $3.60 \%$ & $2.30 \%$ & $18.70 \%$ & $8.42 \%$ & $4.40 \%$ & $5.50 \%$ & $8.10 \%$ & $1.80 \%$ & $8.10 \%$ & $5.58 \%$ \\
\hline 2008 & $8.60 \%$ & $14.00 \%$ & $5.70 \%$ & $8.40 \%$ & $31.40 \%$ & $13.62 \%$ & $8.70 \%$ & $7.00 \%$ & $10.20 \%$ & $5.80 \%$ & $7.90 \%$ & $7.92 \%$ \\
\hline 2009 & $6.30 \%$ & $3.30 \%$ & $4.90 \%$ & $5.20 \%$ & $27.10 \%$ & $9.36 \%$ & $0.10 \%$ & $4.20 \%$ & $2.60 \%$ & $2.90 \%$ & $7.10 \%$ & $3.38 \%$ \\
\hline 2010 & $10.80 \%$ & $2.50 \%$ & $5.00 \%$ & $3.60 \%$ & $28.20 \%$ & $10.02 \%$ & $1.40 \%$ & $2.30 \%$ & $4.70 \%$ & $1.50 \%$ & $6.70 \%$ & $3.32 \%$ \\
\hline 2011 & $9.50 \%$ & $9.80 \%$ & $6.60 \%$ & $4.50 \%$ & $26.10 \%$ & $11.30 \%$ & $3.30 \%$ & $3.40 \%$ & $8.30 \%$ & $3.40 \%$ & $8.10 \%$ & $5.30 \%$ \\
\hline 2012 & $10.00 \%$ & $4.60 \%$ & $5.40 \%$ & $5.10 \%$ & $21.10 \%$ & $9.24 \%$ & $3.00 \%$ & $3.20 \%$ & $3.70 \%$ & $3.70 \%$ & $8.10 \%$ & $4.34 \%$ \\
\hline 2013 & $10.60 \%$ & $5.70 \%$ & $6.20 \%$ & $2.70 \%$ & $40.60 \%$ & $13.16 \%$ & $1.80 \%$ & $2.00 \%$ & $2.70 \%$ & $2.80 \%$ & $8.60 \%$ & $3.58 \%$ \\
\hline 2014 & $40.28 \%$ & $5.80 \%$ & $6.30 \%$ & $3.60 \%$ & $62.20 \%$ & $23.64 \%$ & $4.40 \%$ & $2.90 \%$ & $5.00 \%$ & $3.20 \%$ & $8.90 \%$ & $4.88 \%$ \\
\hline 2015 & $26.58 \%$ & $4.10 \%$ & $9.00 \%$ & $4.00 \%$ & $121.70 \%$ & $33.08 \%$ & $4.30 \%$ & $5.00 \%$ & $3.10 \%$ & $3.60 \%$ & $8.70 \%$ & $4.94 \%$ \\
\hline
\end{tabular}

Source: Own preparation with information of [35]

According to Table 4, Bolivia is the country with the lowest percentages of FBK into Group 1, although in recent years it has reached the percentages of Brazil. It is also interesting to see the Ecuador case, whose rate is the highest in the region, reaching up to $27 \%$. In the case of Group 2, Chile and Colombia have stable percentages over time, although Peru has risen significantly in recent years, Paraguay is the one with the greatest weakness in its investments. A qualitative analysis will shed more light on the quality of investments since in the Group 1 countries, these probably do not respond to economic considerations, due to the strong state participation in them.

In this analysis, is necessary to take the conclusions with careful, because the size of economies as Brazil compared with Bolivia or Ecuador, for example, show very important differences. Thus, the magnitudes of FBK, yet be a low 
percentage of the GNP in the case of Brazil, is notoriously greater than the other named countries.

Table 4. Gross Formation of Capital (\% of GNP).

\begin{tabular}{|c|c|c|c|c|c|c|c|c|c|c|c|c|}
\hline AÑ̃ & Argentina & Bolivia & Brazil & Ecuador & Venezuela & $\begin{array}{l}\text { Average } \\
\text { Group 1 }\end{array}$ & Chile & Colombia & Paraguay & Peru & Uruguay & $\begin{array}{l}\text { Average } \\
\text { Group 2 } \\
\end{array}$ \\
\hline 2000 & $16.19 \%$ & $17.89 \%$ & $18.30 \%$ & $19.01 \%$ & $21.01 \%$ & $18.48 \%$ & $21.03 \%$ & $14.13 \%$ & $15.44 \%$ & $19.67 \%$ & $14.32 \%$ & $16.92 \%$ \\
\hline 2001 & $14.18 \%$ & $13.93 \%$ & $18.42 \%$ & $19.05 \%$ & $24.05 \%$ & $17.92 \%$ & $21.63 \%$ & $15.40 \%$ & $15.62 \%$ & $17.97 \%$ & $13.66 \%$ & $16.86 \%$ \\
\hline 2002 & $11.96 \%$ & $15.65 \%$ & $17.93 \%$ & $20.69 \%$ & $21.92 \%$ & $17.63 \%$ & $21.35 \%$ & $16.73 \%$ & $15.20 \%$ & $16.73 \%$ & $12.35 \%$ & $16.47 \%$ \\
\hline 2003 & $15.14 \%$ & $12.66 \%$ & $16.60 \%$ & $19.24 \%$ & $15.47 \%$ & $15.82 \%$ & $21.20 \%$ & $18.11 \%$ & $17.75 \%$ & $16.92 \%$ & $12.52 \%$ & $17.30 \%$ \\
\hline 2004 & $15.89 \%$ & $11.69 \%$ & $17.32 \%$ & $19.70 \%$ & $18.34 \%$ & $16.59 \%$ & $20.27 \%$ & $18.83 \%$ & $18.30 \%$ & $16.79 \%$ & $14.37 \%$ & $17.71 \%$ \\
\hline 2005 & $17.35 \%$ & $12.99 \%$ & $17.06 \%$ & $20.42 \%$ & $20.27 \%$ & $17.62 \%$ & $22.15 \%$ & $19.73 \%$ & $19.15 \%$ & $17.06 \%$ & $16.55 \%$ & $18.93 \%$ \\
\hline 2006 & $18.33 \%$ & $14.30 \%$ & $17.21 \%$ & $20.85 \%$ & $22.33 \%$ & $18.61 \%$ & $19.86 \%$ & $21.51 \%$ & $19.28 \%$ & $17.79 \%$ & $18.24 \%$ & $19.33 \%$ \\
\hline 2007 & $19.52 \%$ & $16.14 \%$ & $18.00 \%$ & $20.77 \%$ & $25.02 \%$ & $19.89 \%$ & $20.72 \%$ & $23.16 \%$ & $17.88 \%$ & $19.99 \%$ & $18.58 \%$ & $20.07 \%$ \\
\hline 2008 & $19.01 \%$ & $17.25 \%$ & $19.39 \%$ & $22.37 \%$ & $22.10 \%$ & $20.02 \%$ & $25.54 \%$ & $20.81 \%$ & $18.96 \%$ & $23.43 \%$ & $20.55 \%$ & $21.86 \%$ \\
\hline 2009 & $15.58 \%$ & $16.48 \%$ & $19.10 \%$ & $22.81 \%$ & $23.53 \%$ & $19.50 \%$ & $22.46 \%$ & $21.79 \%$ & $18.54 \%$ & $22.14 \%$ & $18.74 \%$ & $20.74 \%$ \\
\hline 2010 & $16.64 \%$ & $16.57 \%$ & $20.53 \%$ & $24.62 \%$ & $18.68 \%$ & $19.41 \%$ & $21.55 \%$ & $21.03 \%$ & $21.31 \%$ & $23.51 \%$ & $19.07 \%$ & $21.30 \%$ \\
\hline 2011 & $17.25 \%$ & $18.97 \%$ & $20.61 \%$ & $25.82 \%$ & $17.73 \%$ & $20.08 \%$ & $23.12 \%$ & $21.37 \%$ & $20.97 \%$ & $23.35 \%$ & $19.12 \%$ & $21.59 \%$ \\
\hline 2012 & $15.86 \%$ & $18.36 \%$ & $20.72 \%$ & $26.96 \%$ & $20.31 \%$ & $20.44 \%$ & $24.88 \%$ & $21.25 \%$ & $19.53 \%$ & $25.04 \%$ & $22.15 \%$ & $22.57 \%$ \\
\hline 2013 & $16.29 \%$ & $19.06 \%$ & $20.91 \%$ & $27.55 \%$ & $22.22 \%$ & $21.21 \%$ & $24.80 \%$ & $21.50 \%$ & $19.02 \%$ & $25.30 \%$ & $21.84 \%$ & $22.49 \%$ \\
\hline 2014 & $15.98 \%$ & $20.98 \%$ & $19.87 \%$ & $27.21 \%$ & $21.62 \%$ & $21.13 \%$ & $23.85 \%$ & $22.67 \%$ & $19.83 \%$ & $24.54 \%$ & $21.44 \%$ & $22.47 \%$ \\
\hline 2015 & $15.56 \%$ & $21.37 \%$ & $17.84 \%$ & $26.58 \%$ & & $20.34 \%$ & $23.78 \%$ & $23.37 \%$ & $19.43 \%$ & $23.09 \%$ & $19.79 \%$ & $21.89 \%$ \\
\hline
\end{tabular}

Source: Own preparation with information of [35]

According to the previous analysis, the performance of Group 1 economies has not been as promising as had been promised, although at first its economic growth is important. It is necessary to recognize in this group of countries, the very high weight of the Brazilian economy, which, when entering a period of crisis, largely explains the collapse of the group's economic results. Similarly, inflation levels have shown greater volatility in the countries of Group 1 and a growing trend in the 15 years covered by data series, an inverse situation is happening in Group 2 countries. Both variables show less economic predictability in Group 1 countries.

Regarding climate for private entrepreneurship, the WEF
Total Tax Rate indicator (in Table 5) for 2015 shows that the sum of different tax contributions as a percentage of commercial profits, on average, reaches $78 \%$ in Group 1 . Indeed, Ecuador is the country with the lowest rate (34.79) and Argentina having the highest rate (137.4). In the Argentina case, it is striking that the State takes a larger portion of the profits than the investor himself. In Group 2, except for Colombia, the Total Tax Rate is concentrated around the average (42.26\% in 2015), with Colombia as the country with the highest rate with 69.70 . It is important to remark that the country of reference (USA) has a rate of $43.8 \%$, a very similar rate to Group 2 countries.

Table 5. Total Tax Rate: Sum of profit tax, labor tax and social contributions, property taxes, turnover taxes, and other taxes, as a share (\%) of commercial profits.

\begin{tabular}{|c|c|c|c|c|c|c|c|c|c|c|c|c|c|c|}
\hline Year & Argentina & Bolivia & Brazil & Ecuador & Venezuela & $\begin{array}{l}\text { Group } 1 \\
\text { Average }\end{array}$ & Chile & Colombia & Paraguay & Peru & Uruguay & $\begin{array}{l}\text { Group } 2 \\
\text { Average }\end{array}$ & $\begin{array}{l}\text { Difference } \\
(\%)\end{array}$ & $\begin{array}{l}\text { Reference } \\
\text { Country }\end{array}$ \\
\hline 2008 & 108.10 & 80.00 & 69.20 & 34.90 & 61.10 & 70.66 & 25.30 & 78.70 & 35.00 & 40.30 & 46.70 & 45.20 & 0.56 & 46.30 \\
\hline $2009^{1}$ & 108.15 & 80.00 & 69.10 & 35.10 & 56.85 & 69.84 & 25.15 & 78.70 & 35.00 & 40.25 & 44.35 & 44.69 & 0.56 & 46.55 \\
\hline $2010^{1}$ & 108.20 & 80.00 & 69.00 & 35.30 & 52.60 & 69.02 & 25.00 & 78.70 & 35.00 & 40.20 & 42.00 & 44.18 & 0.56 & 46.80 \\
\hline 2011 & 108.25 & 81.70 & 69.15 & 34.95 & 57.65 & 70.34 & 26.55 & 76.55 & 35.00 & 40.35 & 42.00 & 44.09 & 0.60 & 46.75 \\
\hline 2012 & 108.30 & 83.40 & 69.30 & 34.60 & 62.70 & 71.66 & 28.10 & 74.40 & 35.00 & 40.50 & 42.00 & 44.00 & 0.63 & 46.70 \\
\hline 2013 & 137.30 & 83.70 & 69.00 & $34.97^{1}$ & 65.50 & 78.09 & 27.90 & 75.40 & 35.00 & 36.00 & 41.80 & 43.22 & 0.81 & 43.80 \\
\hline \multirow[t]{2}{*}{2015} & 137.40 & 83.70 & 69.20 & $34.97^{1}$ & 65.00 & 78.05 & 28.90 & 69.70 & 35.00 & 35.90 & 41.80 & 42.26 & 0.85 & 43.80 \\
\hline & \multicolumn{14}{|c|}{${ }^{1}$ Data not available, so an estimate was made. } \\
\hline
\end{tabular}

Source: Own preparation with information of [36]

Table 6 presents the time required to start a new business. The results found show a sharp difference between both groups of countries. In Group 1 in 2015 it took 70.6 days on average, while in Group 2, it took 17 days. Venezuela and Brazil have a very significant impact on the Group 1 average, in these countries at 2015, between 144 and 83 days, respectively, are necessaries to start a business. On the contrary, in Group 2 only in Paraguay and Peru, it takes more than 20 days in starting a business, while in Chile and Uruguay it takes only between 6 and 7 days, respectively, with timeframe like that of the cites reference country.

Table 6. Number of days required to start a business.

\begin{tabular}{|c|c|c|c|c|c|c|c|c|c|c|c|c|c|c|}
\hline Year & Argentina & Bolivia & Brazil & Ecuador & Venezuela & $\begin{array}{l}\text { Group } 1 \\
\text { Average }\end{array}$ & Chile & Colombia & Paraguay & Peru & Uruguay & $\begin{array}{l}\text { Group } 2 \\
\text { Average }\end{array}$ & $\begin{array}{l}\text { Difference } \\
(\%)\end{array}$ & $\begin{array}{l}\text { Reference } \\
\text { Country }\end{array}$ \\
\hline 2009 & 81 & 50 & 120 & 64 & 141 & 91.20 & 27 & 20 & 35 & 41 & 65 & 37.60 & $143 \%$ & 6 \\
\hline 2010 & 26 & 50 & 120 & 56 & 141 & 78.60 & 22 & 14 & 35 & 27 & 65 & 32.60 & $141 \%$ & 6 \\
\hline
\end{tabular}




\begin{tabular}{|c|c|c|c|c|c|c|c|c|c|c|c|c|c|c|}
\hline Year & Argentina & Bolivia & Brazil & Ecuador & Venezuela & $\begin{array}{l}\text { Group } 1 \\
\text { Average } \\
\end{array}$ & Chile & Colombia & Paraguay & Peru & Uruguay & $\begin{array}{l}\text { Group } 2 \\
\text { Average }\end{array}$ & $\begin{array}{l}\text { Difference } \\
(\%)\end{array}$ & $\begin{array}{l}\text { Reference } \\
\text { Country }\end{array}$ \\
\hline $2011^{1}$ & 26 & 50 & 120 & 56 & 143 & 78.80 & 15 & 14 & 35 & 27 & 36 & 25.20 & $213 \%$ & 6 \\
\hline 2012 & 26 & 50 & 119 & 56 & 144 & 79.00 & 8 & 13 & 35 & 26 & 7 & 17.80 & $344 \%$ & 6 \\
\hline 2013 & 25 & 49 & 108 & 56 & 144 & 76.40 & 6 & 15 & 35 & 25 & 7 & 17.60 & $334 \%$ & 5 \\
\hline 2014 & 25 & 49 & 84 & $56^{1}$ & 144 & 71.60 & 6 & 11 & 35 & 26 & 7 & 17.00 & $321 \%$ & 6 \\
\hline 2015 & 25 & 50 & 83 & 51 & 144 & 70.60 & 6 & 11 & 35 & 26 & 7 & 17.00 & $315 \%$ & 6 \\
\hline & \multicolumn{14}{|c|}{${ }^{1}$ Data not available, so an estimate was made. } \\
\hline
\end{tabular}

Source: Own preparation with information of [36]

Table 7. Number of procedures required to start a business.

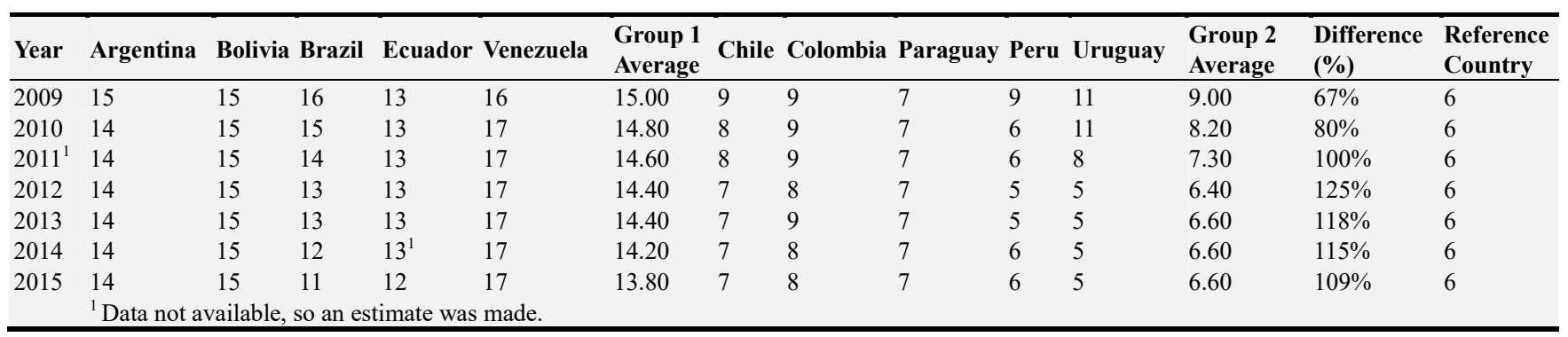

Source: Own preparation with information of [36]

Table 7 shows the number of procedures required to set up a business, presenting a situation quite like that observed with the preceding indicator in both groups of countries. In this case, in the Group 1 countries 14 types of procedures are necessaries for to start a business, the same initiative in the Group 2 countries would take only 6 days.

The Group 1 countries in all cases have more than 12 procedures or legal requirements, while Group 2, have in average, a number quite close to the reference's country.

It is understood that the higher the costs of undertaking an economic activity are, the less attractive the investment is. In this sense, high tax levels and dilatory and bureaucratic procedures discourage private activity and encourage informality. In Group 1 these indicators show that the private sector is not considered an important partner for development. For its part, Group 2 presents better indicators that are quite close to the reference country, which implies that they would be into the same economies path with high levels of economic and social development and with private participation as well.
All the selected indicators respond to the importance that today have telecommunications in economic and social development. Regarding the standards ICT indicators and the importance that States give to them: Those have shown that in Group 2 there is greater sensitivity towards ICT to impulse the development.

From countries review, it can be seen that Venezuela and Argentina have taken less into account the importance of adequate regulatory support for the development of ICT and to improve their country's overall competitiveness, with an index of only 2.4 and 2.6 respectively, compared to 4.7 for the reference country and very far from 7 , the optimal value of this index. Currently, Ecuador with a 3.9, is the one that shows more sensitivity in this Group. On the other hand, the Group 2 countries, without being in expectation levels, are less far from the ideal value, where Paraguay and Peru (2.9 and 3.1, respectively) are with less normative development, and Colombia with 4,3 is the country that gives more importance to ICT for the future (see detail at the top of Table 8).

\subsection{Telecommunications Sector}

Table 8. Importance of ICT to government vision of the future: To what extent does the government have a clear implementation plan for utilizing information and communication technologies to improve your country's overall competitiveness? [1= no plan; $7=$ clear plan] $\mid 2009-2010$ weighted average.

\begin{tabular}{|c|c|c|c|c|c|c|c|c|c|c|c|c|c|c|}
\hline Year & Argentina & Bolivia & Brazil & Ecuador & Venezuela & $\begin{array}{l}\text { Group } 1 \\
\text { Average }\end{array}$ & Chile & Colombia & Paraguay & Peru & Uruguay & $\begin{array}{l}\text { Group } 2 \\
\text { Average }\end{array}$ & $\begin{array}{l}\text { Difference } \\
(\%)\end{array}$ & $\begin{array}{l}\text { Reference } \\
\text { Country }\end{array}$ \\
\hline $2008-2009$ & 2.60 & 2.16 & 4.15 & 2.88 & 2.87 & 2.93 & 4.67 & 4.37 & 2.66 & 3.37 & 4.03 & 3.82 & -0.23 & 4.91 \\
\hline $2009-2010$ & 2.56 & 2.71 & 4.18 & 3.19 & 2.81 & 3.09 & 4.64 & 4.23 & 2.68 & 3.45 & 4.37 & 3.87 & -0.20 & 4.79 \\
\hline $2010-2011^{1}$ & 2.58 & 3.01 & 4.04 & 3.50 & 2.76 & 3.18 & 4.62 & 4.17 & 2.69 & 3.43 & 4.14 & 3.81 & -0.17 & 4.65 \\
\hline $2011-2012$ & 2.60 & 3.30 & 3.90 & 3.80 & 2.70 & 3.26 & 4.60 & 4.10 & 2.70 & 3.40 & 3.90 & 3.74 & -0.13 & 4.50 \\
\hline $2012-2013$ & 2.50 & 3.40 & 3.70 & 4.20 & 2.50 & 3.26 & 4.40 & 4.20 & 2.80 & 3.30 & 3.80 & 3.70 & -0.12 & 4.50 \\
\hline $2013-2104$ & 2.50 & 3.50 & 3.30 & $4.20^{1}$ & 2.40 & 3.18 & 4.20 & 4.40 & 3.00 & 3.30 & 4.00 & 3.78 & -0.16 & 4.40 \\
\hline $2014-2015$ & 2.60 & 3.40 & 3.10 & 3.90 & 2.40 & 3.08 & 3.90 & 4.30 & 2.90 & 3.10 & 4.10 & 3.66 & -0.16 & 4.70 \\
\hline
\end{tabular}


Regarding the access cost, in Table 9 in Venezuela the people must allocate up to $11.38 \%$ of GDP per capita to access a gigabyte of navigation, while that same gigabyte in Uruguay implies only $0,52 \%$ of its GDP per capita. It is not possible to do an appropriated group generalization, due to the disparity of the results, because the high average of Group 1 is mainly explained by Venezuela (see detail in the lower part of Table 9).
A similar thing occurs with access to fixed broadband Internet. Table 9 in its upper part, shows that in Group 1 there are two extremes by 2015: Brazil is the country with the cheapest fixed broadband internet in South America and Bolivia is the most expensive one. With these results, it is not possible to obtain any definitive conclusion, but in average in the countries of Group 2 is cheaper than in the other one group to access to Internet by broadband fixed.

Table 9. Cost of the Cheapest Broadband Plan as \% of Per capita GDP.

\begin{tabular}{|c|c|c|c|c|c|c|c|c|c|c|c|c|}
\hline Year & Argentina & Bolivia & Brazil & Ecuador & Venezuela & $\begin{array}{l}\text { Group } 1 \\
\text { Average }\end{array}$ & Chile & Colombia & Paraguay & Peru & Uruguay & $\begin{array}{l}\text { Group } 2 \\
\text { Average }\end{array}$ \\
\hline \multicolumn{13}{|c|}{ Fixed Broadband } \\
\hline 2010 & 2.40 & 22.10 & 1.80 & 4.70 & 0.90 & 6.38 & 2.30 & 4.00 & 5.60 & 6.20 & 1.10 & 3.84 \\
\hline 2011 & 1.80 & 13.70 & 1.80 & 4.60 & 0.60 & 4.50 & 1.80 & 3.50 & 6.40 & 5.40 & 0.80 & 3.58 \\
\hline 2012 & 2.10 & 11.70 & 1.60 & 4.30 & 0.60 & 4.06 & 1.60 & 2.90 & 6.50 & 3.50 & 0.70 & 3.04 \\
\hline 2013 & 2.10 & 10.50 & 1.60 & 4.10 & 0.80 & 3.82 & 1.80 & 2.70 & 4.90 & 3.40 & 1.00 & 2.76 \\
\hline 2014 & 2.50 & 8.60 & 1.50 & 2.00 & & 3.65 & 1.80 & 1.50 & 4.40 & 3.80 & 0.90 & 2.48 \\
\hline \multicolumn{13}{|c|}{ Mobil Broadband } \\
\hline 2011 & 1.30 & 7.50 & 2.40 & 3.90 & 2.10 & 3.44 & 2.30 & 2.50 & 5.80 & 4.50 & 1.30 & 3.28 \\
\hline 2012 & 1.10 & 6.80 & 1.70 & 6.90 & 2.10 & 3.72 & 1.60 & 2.50 & 3.50 & 1.40 & 0.80 & 1.96 \\
\hline 2013 & 1.40 & 6.00 & 3.20 & 5.50 & 1.90 & 3.60 & 0.80 & 2.20 & 4.00 & 1.40 & 1.00 & 1.88 \\
\hline 2014 & 1.10 & 2.90 & 2.40 & 3.10 & & 2.38 & 1.40 & 0.80 & 3.60 & 2.90 & 0.80 & 1.90 \\
\hline 2015 & 1.46 & 2.91 & 0.94 & 4.12 & 11.38 & 4.16 & 0.77 & 1.63 & 2.42 & 2.49 & 0.52 & 1.57 \\
\hline
\end{tabular}

Source: Own preparation with information of DIRSI (2016) [39]

Finally, access to broadband internet does not allow robust conclusions at groups' level either, but it can be seen in Table 10 that countries, like Argentina, Uruguay or Chile, whose access cost is lower, also have a higher percentage of broadband access. On the other hand, countries such as Bolivia with the highest access cost has the lowest access percentage.

Table 10. Internet Coverage by Countries - Users per 100 people (WB, 2016).

\begin{tabular}{|c|c|c|c|c|c|c|c|c|c|c|c|c|}
\hline Year & Argentina & Bolivia & Brazil & Ecuador & Venezuela & $\begin{array}{l}\text { Group } 1 \\
\text { Average }\end{array}$ & Chile & Colombia & Paraguay & Peru & Uruguay & $\begin{array}{c}\text { Group } 2 \\
\text { Average }\end{array}$ \\
\hline 2000 & $7.00 \%$ & $1.40 \%$ & $2.90 \%$ & $1.50 \%$ & $3.40 \%$ & $3.24 \%$ & $16.60 \%$ & $2.20 \%$ & $0.70 \%$ & $3.10 \%$ & $10.50 \%$ & $6.62 \%$ \\
\hline 2001 & $9.80 \%$ & $2.10 \%$ & $4.50 \%$ & $2.70 \%$ & $4.60 \%$ & $4.74 \%$ & $19.10 \%$ & $2.90 \%$ & $1.10 \%$ & $7.60 \%$ & $11.10 \%$ & $8.36 \%$ \\
\hline 2002 & $10.90 \%$ & $3.10 \%$ & $9.10 \%$ & $4.30 \%$ & $4.90 \%$ & $6.46 \%$ & $22.10 \%$ & $4.60 \%$ & $1.80 \%$ & $9.00 \%$ & $11.40 \%$ & $9.78 \%$ \\
\hline 2003 & $11.90 \%$ & $3.50 \%$ & $13.20 \%$ & $4.50 \%$ & $7.50 \%$ & $8.12 \%$ & $25.50 \%$ & $7.40 \%$ & $2.10 \%$ & $11.60 \%$ & $15.90 \%$ & $12.50 \%$ \\
\hline 2004 & $16.00 \%$ & $4.40 \%$ & $19.10 \%$ & $4.80 \%$ & $8.40 \%$ & $10.54 \%$ & $28.20 \%$ & $9.10 \%$ & $3.50 \%$ & $14.10 \%$ & $17.10 \%$ & $14.40 \%$ \\
\hline 2005 & $17.70 \%$ & $5.20 \%$ & $21.00 \%$ & $6.00 \%$ & $12.60 \%$ & $12.50 \%$ & $31.20 \%$ & $11.00 \%$ & $7.90 \%$ & $17.10 \%$ & $20.10 \%$ & $17.46 \%$ \\
\hline 2007 & $25.90 \%$ & $10.50 \%$ & $30.90 \%$ & $10.80 \%$ & $20.80 \%$ & $19.78 \%$ & $35.90 \%$ & $21.80 \%$ & $11.20 \%$ & $25.20 \%$ & $34.00 \%$ & $25.62 \%$ \\
\hline 2008 & $28.10 \%$ & $12.50 \%$ & $33.80 \%$ & $18.80 \%$ & $25.90 \%$ & $23.82 \%$ & $37.30 \%$ & $25.60 \%$ & $14.30 \%$ & $30.60 \%$ & $39.30 \%$ & $29.42 \%$ \\
\hline 2009 & $34.00 \%$ & $16.80 \%$ & $39.20 \%$ & $24.60 \%$ & $32.70 \%$ & $29.46 \%$ & $41.60 \%$ & $30.00 \%$ & $18.90 \%$ & $31.40 \%$ & $41.80 \%$ & $32.74 \%$ \\
\hline 2010 & $45.00 \%$ & $22.40 \%$ & $40.70 \%$ & $29.00 \%$ & $37.40 \%$ & $34.90 \%$ & $45.00 \%$ & $36.50 \%$ & $19.80 \%$ & $34.80 \%$ & $46.40 \%$ & $36.50 \%$ \\
\hline 2011 & $51.00 \%$ & $30.00 \%$ & $45.70 \%$ & $31.40 \%$ & $40.20 \%$ & $39.66 \%$ & $52.20 \%$ & $40.40 \%$ & $24.80 \%$ & $36.00 \%$ & $51.40 \%$ & $40.96 \%$ \\
\hline 2012 & $55.80 \%$ & $35.30 \%$ & $48.60 \%$ & $35.10 \%$ & $49.10 \%$ & $44.78 \%$ & $61.40 \%$ & $49.00 \%$ & $29.30 \%$ & $38.20 \%$ & $54.50 \%$ & $46.48 \%$ \\
\hline 2013 & $59.90 \%$ & $36.90 \%$ & $51.00 \%$ & $40.40 \%$ & $54.90 \%$ & $48.62 \%$ & $66.50 \%$ & $51.70 \%$ & $36.90 \%$ & $39.20 \%$ & $57.70 \%$ & $50.40 \%$ \\
\hline
\end{tabular}

Source: Own preparation with information of [35]

\subsection{Electrical Sector}

The analysis of selected indicators of the electricity sector, as seen in Table 11, shows that Bolivia is the country with the lowest per-capita energy consumption (kWh per capita), by far, and in the region, together with Peru and Ecuador are the countries with the lowest consumption rates. For its part, Chile and Venezuela have the most per capita consumption. In this case, the difference in consumption seems to be attributable more to issues related to income level, general economic development and other country conditions, including price policies ${ }^{2}$.

2In case of Venezuela, there are important subsidies for energy, and in Bolivia tariffs are practically frozen, because by decree, they can't go up more than $3 \%$ into a tariffari period. 
Table 11. Per Capita Consumption of Electric Energy.

\begin{tabular}{|c|c|c|c|c|c|c|c|c|c|c|c|c|}
\hline Year & Argentina & Bolivia & Brazil & Ecuador & Venezuela & $\begin{array}{l}\text { Group } 1 \\
\text { Average }\end{array}$ & Chile & Colombia & Paraguay & Peru & Uruguay & $\begin{array}{l}\text { Group 2 } \\
\text { Average }\end{array}$ \\
\hline 2000 & $2,078.29$ & 419.81 & $1,886.60$ & 637.52 & $2,636.12$ & $1,531.67$ & $2,527.62$ & 829.40 & 887.47 & 680.19 & $2,030.26$ & $1,390.99$ \\
\hline 2001 & $2,109.49$ & 420.77 & $1,735.95$ & 649.98 & $2,700.22$ & $1,523.28$ & $2,655.68$ & 850.43 & 873.93 & 706.06 & $2,000.24$ & $1,417.26$ \\
\hline 2002 & $2,003.43$ & 434.40 & $1,791.62$ & 692.24 & $2,726.12$ & $1,529.56$ & $2,752.41$ & 858.62 & 884.80 & 740.82 & $1,997.73$ & $1,446.88$ \\
\hline 2003 & $2,167.71$ & 441.98 & $1,863.63$ & 720.11 & $2,633.20$ & $1,565.33$ & $2,919.97$ & 862.52 & 839.52 & 764.99 & $1,884.45$ & $1,454.29$ \\
\hline 2004 & $2,279.29$ & 452.18 & $1,933.98$ & 829.11 & $2,762.93$ & $1,651.50$ & $3,084.06$ & 898.34 & 828.23 & 802.84 & $1,928.95$ & $1,508.48$ \\
\hline 2005 & $2,392.89$ & 482.17 & $1,990.64$ & 799.77 & $2,850.19$ & $1,703.13$ & $3,112.22$ & 895.82 & 863.77 & 837.29 & $1,999.63$ & $1,541.75$ \\
\hline 2006 & $2,357.96$ & 513.07 & $2,044.86$ & 868.16 & $2,958.43$ & $1,748.49$ & $3,237.22$ & 947.13 & 920.82 & 887.62 & $2,220.93$ & $1,642.74$ \\
\hline 2007 & $2,438.01$ & 545.36 & $2,137.76$ & 958.93 & $2,973.00$ & $1,810.61$ & $3,353.16$ & 974.39 & 984.05 & 968.13 & $2,413.35$ & $1,738.61$ \\
\hline 2008 & $2,752.13$ & 534.48 & $2,198.48$ & $1,083.99$ & $3,071.80$ & $1,928.18$ & $3,350.79$ & 974.22 & $1,033.55$ & $1,039.45$ & $2,586.22$ & $1,796.85$ \\
\hline 2009 & $2,708.99$ & 553.65 & $2,165.68$ & $1,111.20$ & $3,033.87$ & $1,914.68$ & $3,307.55$ & $1,049.98$ & $1,092.88$ & $1,040.63$ & $2,659.72$ & $1,830.15$ \\
\hline 2010 & $2,847.33$ & 604.34 & $2,339.44$ & $1,143.78$ & $3,134.43$ & $2,013.86$ & $3,316.18$ & $1,077.98$ & $1,178.61$ & $1,094.31$ & $2,803.15$ & $1,894.05$ \\
\hline 2011 & $2,901.36$ & 637.31 & $2,394.40$ & $1,217.35$ & $3,196.89$ & $2,069.46$ & $3,590.31$ & $1,121.40$ & $1,282.54$ & $1,241.67$ & $2,808.36$ & $2,008.85$ \\
\hline 2012 & $2,954.54$ & 663.36 & $2,463.28$ & $1,281.56$ & $3,249.79$ & $2,122.51$ & $3,810.12$ & $1,149.95$ & $1,368.05$ & $1,211.32$ & $2,931.03$ & $2,094.10$ \\
\hline 2013 & $3,093.35$ & 705.29 & $2,529.30$ & $1,333.16$ & $3,245.07$ & $2,181.24$ & $3,878.91$ & $1,177.11$ & $1,473.01$ & $1,269.77$ & $2,985.06$ & $2,156.77$ \\
\hline 2014 & $3,075.00$ & 743.00 & $2,620.00$ & $1,376.00$ & $2,719.00$ & $2,106.60$ & $3,880.00$ & $1,312.00$ & $1,552.00$ & $1,346.00$ & $3,085.00$ & $2,235.00$ \\
\hline
\end{tabular}

Source: Own preparation with information of [35]

On the other hand, the current coverage at groups levels is very homogeneous. Bolivia has the lowest coverage (90.5\%) followed by Peru (91.2\%). Venezuela would the only country with $100 \%$ coverage, although several countries are close to $99 \%$ (See Table 12).

Table 12. Electrical Coverage by Countries.

\begin{tabular}{|c|c|c|c|c|c|c|c|c|c|c|c|c|}
\hline Year & Argentina & Bolivia & Brazil & Ecuador & Venezuela & $\begin{array}{l}\text { Group } 1 \\
\text { Average }\end{array}$ & Chile & Colombia & Paraguay & Perú & Uruguay & $\begin{array}{l}\text { Group } 2 \\
\text { Average }\end{array}$ \\
\hline 2000 & $95.27 \%$ & $55.27 \%$ & $94.50 \%$ & $88.19 \%$ & $93.90 \%$ & $85.43 \%$ & $94.20 \%$ & $90.26 \%$ & $82.08 \%$ & $63.78 \%$ & $96.26 \%$ & $85.32 \%$ \\
\hline 2001 & $94.43 \%$ & $56.54 \%$ & $94.92 \%$ & $89.67 \%$ & $96.05 \%$ & $86.32 \%$ & $94.70 \%$ & $90.92 \%$ & $85.54 \%$ & $65.16 \%$ & $96.39 \%$ & $86.54 \%$ \\
\hline 2002 & $94.60 \%$ & $58.53 \%$ & $95.33 \%$ & $90.07 \%$ & $96.88 \%$ & $87.08 \%$ & $95.21 \%$ & $91.58 \%$ & $89.14 \%$ & $66.57 \%$ & $96.41 \%$ & $87.78 \%$ \\
\hline 2003 & $94.78 \%$ & $60.58 \%$ & $95.75 \%$ & $90.47 \%$ & $96.45 \%$ & $87.61 \%$ & $95.35 \%$ & $92.25 \%$ & $93.28 \%$ & $68.01 \%$ & $96.84 \%$ & $89.15 \%$ \\
\hline 2004 & $94.95 \%$ & $62.71 \%$ & $96.17 \%$ & $90.88 \%$ & $96.26 \%$ & $88.19 \%$ & $95.39 \%$ & $92.92 \%$ & $96.49 \%$ & $69.48 \%$ & $97.18 \%$ & $90.29 \%$ \\
\hline 2005 & $95.12 \%$ & $64.91 \%$ & $96.59 \%$ & $91.29 \%$ & $96.29 \%$ & $88.84 \%$ & $95.77 \%$ & $93.60 \%$ & $97.75 \%$ & $70.98 \%$ & $97.40 \%$ & $91.10 \%$ \\
\hline 2006 & $95.30 \%$ & $67.18 \%$ & $97.02 \%$ & $91.70 \%$ & $96.51 \%$ & $89.54 \%$ & $96.37 \%$ & $94.28 \%$ & $98.50 \%$ & $72.52 \%$ & $98.52 \%$ & $92.04 \%$ \\
\hline 2007 & $95.47 \%$ & $69.54 \%$ & $97.44 \%$ & $92.11 \%$ & $96.88 \%$ & $90.29 \%$ & $97.04 \%$ & $94.83 \%$ & $98.79 \%$ & $74.09 \%$ & $99.40 \%$ & $92.83 \%$ \\
\hline 2008 & $95.65 \%$ & $71.98 \%$ & $97.87 \%$ & $92.52 \%$ & $97.37 \%$ & $91.08 \%$ & $97.64 \%$ & $95.20 \%$ & $98.86 \%$ & $75.62 \%$ & $99.74 \%$ & $93.41 \%$ \\
\hline 2009 & $95.82 \%$ & $74.51 \%$ & $98.30 \%$ & $92.94 \%$ & $97.90 \%$ & $91.89 \%$ & $97.99 \%$ & $95.39 \%$ & $98.95 \%$ & $77.48 \%$ & $99.74 \%$ & $93.91 \%$ \\
\hline 2010 & $96.00 \%$ & $77.10 \%$ & $98.73 \%$ & $93.35 \%$ & $98.42 \%$ & $92.72 \%$ & $98.00 \%$ & $95.41 \%$ & $98.97 \%$ & $79.31 \%$ & $99.75 \%$ & $94.29 \%$ \\
\hline 2011 & $97.90 \%$ & $83.80 \%$ & $99.12 \%$ & $95.28 \%$ & $99.21 \%$ & $95.06 \%$ & $98.80 \%$ & $96.21 \%$ & $98.59 \%$ & $85.26 \%$ & $99.63 \%$ & $95.69 \%$ \\
\hline 2012 & $99.80 \%$ & $90.50 \%$ & $99.50 \%$ & $97.20 \%$ & $100.00 \%$ & $97.40 \%$ & $99.60 \%$ & $97.00 \%$ & $98.20 \%$ & $91.20 \%$ & $99.50 \%$ & $97.10 \%$ \\
\hline
\end{tabular}

Source: Own preparation with information of [35]

Table 13. Electric Losses as Percentage of Total Generated.

\begin{tabular}{|c|c|c|c|c|c|c|c|c|c|c|c|c|}
\hline Year & Argentina & Bolivia & Brazil & Ecuador & Venezuela & $\begin{array}{l}\text { Group } 1 \\
\text { Average }\end{array}$ & Chile & Colombia & Paraguay & Peru & Uruguay & $\begin{array}{l}\text { Group } 2 \\
\text { Average }\end{array}$ \\
\hline 2000 & $14.83 \%$ & $10.18 \%$ & $17.66 \%$ & $24.13 \%$ & $24.26 \%$ & $18.21 \%$ & $7.29 \%$ & $22.39 \%$ & $2.67 \%$ & $11.48 \%$ & $18.53 \%$ & $12.47 \%$ \\
\hline 2001 & $14.26 \%$ & $10.40 \%$ & $17.24 \%$ & $24.60 \%$ & $25.24 \%$ & $18.35 \%$ & $7.36 \%$ & $19.37 \%$ & $3.21 \%$ & $10.76 \%$ & $15.98 \%$ & $11.34 \%$ \\
\hline 2002 & $17.17 \%$ & $10.37 \%$ & $16.74 \%$ & $24.35 \%$ & $24.76 \%$ & $18.68 \%$ & $6.18 \%$ & $19.40 \%$ & $3.24 \%$ & $10.35 \%$ & $16.73 \%$ & $11.18 \%$ \\
\hline 2003 & $15.27 \%$ & $10.32 \%$ & $16.27 \%$ & $26.23 \%$ & $25.49 \%$ & $18.72 \%$ & $6.09 \%$ & $19.49 \%$ & $3.64 \%$ & $10.11 \%$ & $20.89 \%$ & $12.04 \%$ \\
\hline 2004 & $15.42 \%$ & $10.35 \%$ & $16.75 \%$ & $25.48 \%$ & $26.62 \%$ & $18.92 \%$ & $7.88 \%$ & $19.52 \%$ & $4.24 \%$ & $9.73 \%$ & $30.73 \%$ & $14.42 \%$ \\
\hline 2005 & $15.13 \%$ & $10.13 \%$ & $16.59 \%$ & $26.80 \%$ & $27.05 \%$ & $19.14 \%$ & $8.65 \%$ & $19.51 \%$ & $4.63 \%$ & $9.34 \%$ & $23.33 \%$ & $13.09 \%$ \\
\hline 2006 & $15.12 \%$ & $10.13 \%$ & $16.82 \%$ & $24.99 \%$ & $26.57 \%$ & $18.73 \%$ & $8.86 \%$ & $19.45 \%$ & $4.95 \%$ & $9.32 \%$ & $18.43 \%$ & $12.20 \%$ \\
\hline 2007 & $16.72 \%$ & $10.20 \%$ & $16.14 \%$ & $21.82 \%$ & $27.50 \%$ & $18.48 \%$ & $8.43 \%$ & $20.19 \%$ & $5.06 \%$ & $8.49 \%$ & $12.20 \%$ & $10.87 \%$ \\
\hline 2008 & $13.38 \%$ & $11.79 \%$ & $16.65 \%$ & $19.23 \%$ & $27.21 \%$ & $17.65 \%$ & $8.51 \%$ & $19.30 \%$ & $5.25 \%$ & $8.20 \%$ & $11.79 \%$ & $10.61 \%$ \\
\hline 2009 & $14.75 \%$ & $11.73 \%$ & $17.19 \%$ & $18.00 \%$ & $27.23 \%$ & $17.78 \%$ & $10.55 \%$ & $14.71 \%$ & $5.70 \%$ & $8.16 \%$ & $12.77 \%$ & $10.38 \%$ \\
\hline 2010 & $13.43 \%$ & $11.55 \%$ & $16.63 \%$ & $16.86 \%$ & $20.11 \%$ & $15.72 \%$ & $8.22 \%$ & $15.38 \%$ & $6.23 \%$ & $10.13 \%$ & $11.02 \%$ & $10.19 \%$ \\
\hline 2011 & $14.43 \%$ & $11.03 \%$ & $16.46 \%$ & $16.30 \%$ & $20.46 \%$ & $15.74 \%$ & $7.13 \%$ & $12.18 \%$ & $5.96 \%$ & $5.81 \%$ & $12.44 \%$ & $8.70 \%$ \\
\hline 2012 & $13.69 \%$ & $11.34 \%$ & $17.07 \%$ & $14.50 \%$ & $20.64 \%$ & $15.45 \%$ & $5.02 \%$ & $12.38 \%$ & $6.38 \%$ & $8.47 \%$ & $12.19 \%$ & $8.89 \%$ \\
\hline 2013 & $16.01 \%$ & $9.03 \%$ & $16.40 \%$ & $12.95 \%$ & $20.81 \%$ & $15.04 \%$ & $6.69 \%$ & $11.77 \%$ & $5.78 \%$ & $10.51 \%$ & $10.99 \%$ & $9.15 \%$ \\
\hline
\end{tabular}

Source: Own preparation with information of [35]

However, Venezuela has a very high cost in efficiency since its losses more than $20 \%$ of their total generated power.
Paradoxically, Bolivia is also the country with the lowest losses. All in all, except for Bolivia, Group 2 countries have 
lower levels than Group 1 countries (See Table 13). One possible explanation for this issue is that the cost of reaching high levels of coverage in Group 1 has been the efficiency loss.

Based on the previous analysis and the extensive literature on this subject, it is possible to affirm that there is important evidence that shows that the market plus adequate regulation allows obtaining better economic results. An aspect that seems to be aligned with what was sustained by the works of [13] concerning the incentives of state enterprises to seek efficiency, with $[8,9,10]$ and [40], who argue that an effective and efficient regulation turns out to be advantageous compared with State property, and, among other reasons, with that established by [1] referred to the need for independent regulation and clear rules and institutional strength, to achieve better economic and social results.

\section{Conclusions}

1. In light of the outcomes, there is reasonable doubt about the benefits of the model advocated by Group 1 countries (neo-populist countries), based on the performance of the GDP growth rate and inflation, it is possible to affirm that they have more volatile and less predictable markets. Likewise, in Telecommunications and electricity industries, there is evidence of less efficient performance in countries of Group 1 in relation or Group 2 countries (neo-liberal countries).

In other words, contrary to what is proclaimed by the defenders of the neo-populist governments, during the period under analysis, the results of Group 1 countries, in terms of economic welfare, are not better than those of Group 2 countries.

In summary, the evidence found doesn't show that the economic model adopted by governments of Group 1 countries, would have laid better foundations for economic and social development.

2. In countries under neo-populist governments, the poverty reduction showed at the beginning of the reforms, look likes to have been achieved more as result of the initial redistribution partial of current wealth (through bonuses and other populist measures).

The tax increases and the nationalization or confiscation of private property rather than growth of national wealth seems only reached reduce the incentives and attractiveness for private investment.

This can be verified, for example, in the fact that business climate indicators show a deterioration that affects the private sector and as consequence in reduction of private investment.

3. Likewise, the analysis shows that the neo-populism governments:

(i). don't seem to consider telecommunications as a fundamental development factor, and in particular,

(ii). they don't consider important the contribution of the private sector for telecommunications development,

(iii). they show important barriers to ICTs access, and, therefore, (iv). they have Internet access levels lower than Group 2 countries and, the population less favored don't have the possibility to benefit from technologic advance.

4. In the electricity sector, although there are no obvious findings as in the case of telecommunications, the greatest difficulties seem to begin when is analyzed the access to the service.

The difficulties by to reach to distant populations with the electric services translate into general deterioration in service efficiency. In effect, the greater effort shown by the countries of Group 1 by to reach the universalization of service, entails a deterioration in efficiency, as it is observed through the loss factor.

This deterioration may affect in the long term, to the population as a whole. In this case, the design of a new economic policy is necessary to make efforts to universalize access to electricity sustainable.

These findings motivate to deepen analysis, through the construction of parameterized models, to establish causal relationships between the variables analyzed and to ratify or reject the preliminary findings shown here.

\section{References}

[1] Chong, Alberto and Benavides, Juan (2007), Privatization and regulation in Latin America, The state of state reforms in Latin America Cap. 8

[2] Oszlak, Oscar (2004) Privatization and Capacity for State Regulation: A Theoretical Approach to Methodology, Policy and Public Management - Fund of Economic Culture, CLAD, Buenos Aires.

[3] Dávalos, Arturo (2016) Comparative Analysis of the Electricity and Telecommunications Market: Performance of the Countries in an Environment with Uncertainty and Structural Changes, XXI CLAD International Congress on Reform of the State and Public Administration CLAD, Santiago, Chile.

[4] Stiglitz, J. E. (1992). Asymmetric Information in Credit Markets and its Implications for Macro-Economics. Oxford University Papers, Pp. 694-724.

[5] Stiglitz, J. E. (2003) The economy of the public sector, Antoni Bosch ed., 2003, Part Two.

[6] Ferguson, C. E.; Gould, J. P. T. Microeconomic, Economic Culture Fund of Spain, 1990.

[7] Neuman, Manfred (2001). Competition Policy: History, Theory and Practice. Cap 1.

[8] Kikeri, Sunita and Nellis, John (2004), An Assessment of Privatization. World Bank Research Observer Volume 19, Pages: $87-118$.

[9] Arrow, Kenneth J. (1996). "Discounting, Morality, and Gaming," Working Papers 97004, Stanford University, Department of Economics.

[10] Dembe, Allard and Boden, Leslie (2000). Moral Hazard: A Question of Morality?, New Solutions a Journal of Environmental and Occupational Health Policy. 
[11] Vickers, John and Yarrow (1988), George. Privatization: An economic analysis. The Mit Press, Cambridge, MA.

[12] La Porta, Rafael et. Al. (1999). Corporate Ownership Around The World. The Journal Of Finance, Vol. Liv, No. 2, April 1999.

[13] Sheshinski, Eytan and López-Calva, Luis (2003). Privatization and Its Benefits: Theory and Evidence, CESifo Economic Studies Volume 49, Pp. 429-459.

[14] Pérez Sánchez, Alfredo (1995), External debt of Latin America: Balance of a decade (1980-1990) pp. 1-4

[15] Del Bufalo, Enzo (2002). Economic Reforms in Latin America. Venezuelan Journal of Economy and Social Sciences, vol. $8 \mathrm{n}^{\circ}$ 2, pp. 129-182

[16] Chong, Alberto and Lopez De Silanes, Florencio (2005). Privatization in Latin America: Myths and Reality. Inteamerican Development Bank - Stanford University Press.

[17] Dávalos, Arturo (2012), Study and Proposal for the Regulation of Services Provided by Public Companies - Second Report (p.p. 4-10), PNUD - UMEP - Paraguay.

[18] Krauze, Enrique (2012), Decalogue of populism, The Nation Argentina, November, 1th, 2012, avalaible in https://www.lanacion.com.ar/1522419-decalogo-delpopulismo.

[19] De la Torre, Carlos (2013). Latin American populism: between democratization and authoritarianism. Friedrich Ebert Stiftung. Available in http://nuso.org/media/documents/ El_populismo_latinoamericano_entre_la_democratizació_y_el _autoritarismo__Junio_2013.pdf.

[20] Aguerre, M. L. (2017). Latin American populism. Law School Magazine, (42), 1-27. https://doi.org/10.22187/rfd201712

[21] Tully, S. (2006). The human right to access electricity. The Electricity Journal, 19 (3), 30-39.

[22] McCorquodale, R., \& Fairbrother, R. (1999). Globalization and human rights. Human Rights Quarterly, 21 (3), 735-766.

[23] Dávalos, Arturo and Espinoza, Lourdes (2005). Why the growing perception of unrest in the face of privatization? 1st. Iberoamerican Congress of Economic Regulation, Santiago Chile, november 2005.

[24] Bitoraje, E. (2011). Management Indicators: Information Tool for Public Management Control. Venezuelan Journal of Public Management Research Group on Management and Public Policies. Year 2 No 2 University of Los Andes, MéridaVenezuela. January - December 2011.

[25] Gámez Gutiérrez, J. (2014). Economic growth is different from integral and sustainable human development: a reflection to contribute to welfare. Traza (9), 72-89.

[26] Mateo T. J. Pablo. (2014) Expansion, imbalances and crisis in Venezuela. An analysis of half a century of capital accumulation. Economic research, vol. LXXIII, núm. 290, pp. 87-119.

[27] Corredor C. and Díaz G. (2008). Economic policies applied in Venezuela during the period 1959-2007. Observatory of the Latin American Economy No 105, November 2008.

[28] Mogrovejo, Rodrigo (2010). Political and economic model of E. Morales and the New State Constitution of Bolivia. Journal of Legal Studies $n^{\circ}$ 10/2010.

[29] Jaramillo-Jassir, Mauricio and Tibocha, Anamaría (2008). Rafael Correa's democratic revolution. Center for Political and International Studies - CEPI-. Faculties of Political Science and Government and of International Relations. Bogotá: Editorial. Rosario University, 2008.

[30] Jácome, Hugo (2007). The economic policy of the Rafael Correa government. Political Analysis Magazine La Tendencia No. 6, November 2008.

[31] Dabat, Alejandro (2003). Historical catastrophe and national awakening in Argentina, Revista de Estudios Latinoamericanos, México.

[32] Dabat, Alejandro (2003). The Course of the Argentine Economy under Kirchnerism. Journal of Economic Literature vol. 9 no. 26. UNAM Institute for Economic Research.

[33] García, Anahí (2009). Economic policy during the administration of L. Inácio Lula da Silva (2003-2008). Governmental Institutions and Processes IV. Magazine $\mathrm{N}^{\mathrm{o}} 8$, December 2009.

[34] Grossman, Sanford J., and Oliver D. Hart. 1986. The costs and benefits of ownership: A theory of vertical and lateral integration. Journal of Political Economy 94 (4): 691-719.

[35] World Bank statistics, obtained of http://databank.worldbank.org/data/reports.aspx?Code=NY.G DP.DEFL.KD.ZG\&id=af3ce82b\&report name=Popular indic ators\&populartype $=$ series\&ispopular $=\mathrm{y} \#$, at date $12 / 08 / \overline{1}$.

[36] World Economic Forum. The global information technology reports 2010 to 2015, documents obtained from https://www.weforum.org/reports, at date 27/07/2016.

[37] García-Zaballos, A. and López-Rivas, R.: Governmental control on socio-economic impact of broadband in LAC countries. IDB, 2012.

[38] McKinsey \& Company, (2011) "Internet Matters: The Net's Sweeping Impact on Growth, Jobs and Prosperity." Briefing Note, McKinsey Global Institute, McKinsey \& Company, May 2011.

[39] Regional Dialogue Organization on the Information Society DIRSI (2016), http://dirsi.net/web/web, accessed at date $12 / 08 / 16$

[40] Allen, F. y Gale. D. (2000a). "Bubbles and Crises," Economic Journal 110, 236-255. 